\title{
Evaluation of geochemical proxies and radiocarbon data from a loess record of the Upper Palaeolithic site Kammern-Grubgraben, Lower Austria
}

\author{
Lilian Reiss ${ }^{1}$, Christian Stüwe ${ }^{1}$, Thomas Einwögerer ${ }^{2}$, Marc Händel $^{2}$, Andreas Maier ${ }^{3}$, Stefan Meng ${ }^{4}$, Kerstin Pasda ${ }^{5}$, \\ Ulrich Simon $^{2}$, Bernd Zolitschka ${ }^{6}$, and Christoph Mayr ${ }^{1,7,8}$ \\ ${ }^{1}$ Institute of Geography, Friedrich-Alexander-Universität Erlangen-Nürnberg, Wetterkreuz 15, 91058 Erlangen, Germany \\ ${ }^{2}$ Austrian Archaeological Institute, Austrian Academy of Sciences, Hollandstrasse 11-13, 1020 Vienna, Austria \\ ${ }^{3}$ Institute of Prehistoric Archaeology, University of Cologne, Bernhard-Feilchenfeld-Strasse 11, 50969 Cologne, Germany \\ ${ }^{4}$ Institute for Geography and Geology, University of Greifswald, Friedrich-Ludwig-Jahnstraße 16/17a, \\ 17489 Greifswald, Germany \\ ${ }^{5}$ Institute of Pre- and Protohistoric Archaeology, Friedrich-Alexander-Universität Erlangen-Nürnberg, \\ Kochstrasse 4/18, 91054 Erlangen, Germany \\ ${ }^{6}$ Institute of Geography, University of Bremen, Celsiusstrasse 2, 28359 Bremen, Germany \\ ${ }^{7}$ Department Earth and Environmental Sciences, Ludwig-Maximilians-Universität München, \\ Richard-Wagner-Strasse 10, 80333 Munich, Germany \\ ${ }^{8}$ GeoBio-Center, Ludwig-Maximilians-Universität München, Richard-Wagner-Strasse 10, 80333 Munich, Germany
}

Correspondence: $\quad$ Lilian Reiss (lilian.reiss@fau.de)

Relevant dates: $\quad$ Received: 28 July 2021 - Revised: 21 December 2021 - Accepted: 14 January 2022 Published: 14 February 2022

How to cite:

Reiss, L., Stüwe, C., Einwögerer, T., Händel, M., Maier, A., Meng, S., Pasda, K., Simon, U., Zolitschka, B., and Mayr, C.: Evaluation of geochemical proxies and radiocarbon data from a loess record of the Upper Palaeolithic site Kammern-Grubgraben, Lower Austria, E\&G Quaternary Sci. J., 71, 23-43, https://doi.org/10.5194/egqsj-71-23-2022, 2022.

Abstract:

Two loess sections from the Upper Palaeolithic site of Kammern-Grubgraben (Lower Austria) were analysed to test geochemical proxies, as well as radiocarbon data of different components, for their reliability and consistency in an archaeological context. Only a reliable basal age (28.9-27.8 ka cal BP) was obtained from charcoal fragments derived from a tundra gley underlying the archaeological horizons and assigned to Greenland Interstadials 3 or 4. Grain size, organic and inorganic geochemistry, and stable isotopes of the fine organic fraction $\left(\delta^{13} \mathrm{C}_{\mathrm{org}}\right)$ and of rhizoconcretions $\left(\delta^{13} \mathrm{C}, \delta^{18} \mathrm{O}\right)$ were analysed to provide information on palaeoenvironmental conditions. Low-resolution geochemical and sedimentological analyses document a humidity-related variability, while $\delta^{13} \mathrm{C}_{\text {org }}$ values indicate predominant $\mathrm{C}_{3}$ vegetation. High-resolution elemental variations derived from $\mathrm{X}$-ray fluorescence scanning exhibit increasing $\mathrm{Ca}$ and decreasing $\mathrm{Fe}$ and $\mathrm{Ti}$ values, indicating drier conditions towards the top. Secondary pedogenic carbonate concretions provide post-sedimentary (Holocene) ages and are not suitable for assessing climate and environmental changes for the Palaeolithic.

Kurzfassung: Ziel dieser Studie ist es, geochemische Proxies sowie verschiedene Materialien für die Radiokohlenstoff-Datierung auf ihre Zuverlässigkeit und Konsistenz an zwei Lößprofilen aus der 
paläolithischen Fundstelle Kammern-Grubgraben in Niederösterreich im archäologischen Kontext zu testen. Nur vereinzelte Holzkohlestückchen lieferten hierfür ein zuverlässiges Alter $(28,9-$ 27,8 ka cal BP). Es stammt aus einem Tundra-Gley von der Basis des Profils, unterhalb der archäologischen Horizonte und wird dem Grönland-Interstadial 3 oder 4 zugeordnet. Korngrößen, organische und anorganische geochemische Analysen, sowie Analysen der stabilen Isotope an der organischen Feinfraktion $\left(\delta^{13} \mathrm{C}_{\text {org }}\right)$ und an Wurzelkonkretionen $\left(\delta^{13} \mathrm{C}, \delta^{18} \mathrm{O}\right)$ wurden vorgenommen, um Informationen über Paläoumweltbedingungen zu erhalten. Die geochemischen Proxies $\left(\mathrm{CaCO}_{3}\right.$, TOCGehalte und C / N-Verhältnisse) weisen auf Variationen der Feuchtigkeit hin, während die $\delta^{13} \mathrm{C}_{\text {org }}{ }^{-}$ Werte eine vorherrschende $\mathrm{C}_{3}$-Vegetation anzeigen. Hochauflösende Elementvariationen, abgeleitet aus Röntgenfluoreszenz-Analysen, deuten zunehmende Ca- bzw. abnehmende Fe- und Ti-Verläufe mit abnehmendem Alter und somit zunehmende Trockenheit an. Die sekundären pedogenen Karbonatkonkretionen besitzen postsedimentäre (holozäne) Alter und sind nicht geeignet, um Klima- und Umweltveränderungen in den untersuchten Profilen zu beurteilen.

\section{Introduction}

During the last glacial, extensive loess deposits accumulated in central Europe between the Fennoscandian Ice Shield and Alpine glaciers (Smalley et al., 2011; Sprafke, 2016; Lehmkuhl et al., 2021). Predominantly, loess sediments are deposited in valleys, in sedimentary basins of low mountain ranges, and along large rivers. Thus, both the distance to the source area of aeolian dust and the local geomorphology have influenced the thickness of loess deposits (Lehmkuhl et al., 2016). A key area of loess research in the Alpine realm is located in Lower Austria at the western edge of the middle Danube basin, where loess landscapes are widespread (Smalley et al., 2009; Sprafke, 2016; Terhorst et al., 2011). Prevailing westerly winds together with dry and cold katabatic winds from the Alps and Fennoscandian ice sheets favoured the transport of mineral dust from glacial forelands and river floodplains (Renssen et al., 2007; Lowe and Walker, 2015). However, heavy-mineral studies on loess suggest that local dust sources initially mobilised by fluvial transport dominate over far-distance sources in the Lower Austrian study area (Újvári and Klötzli, 2015). Fine silty material was transported farther than coarser grains, and loess predominantly accumulated on slopes exposed to the east, i.e. in lee-side positions (Lowe and Walker, 2015; Sprafke, 2016). Loess deposits formed under (peri)glacial conditions (Frechen et al., 2003; Fitzsimmons et al., 2012), while soils developed during milder interglacials or interstadials (Terhorst et al., 2011; Buggle et al., 2009; Bronger, 2003). Therefore, the resulting loess palaeosol sequences (LPSs) reflect Quaternary climate variability with its glacial-interglacial and stadialinterstadial periods (Bronger, 1999; Frechen et al., 2003; Antoine et al., 2009; Buggle et al., 2009; Sprafke, 2016) and represent prominent natural archives for climate and environmental reconstructions (Porter, 2001; Marković et al., 2015; Lehmkuhl et al., 2016). Different sedimentological or pedological proxies are used for reconstructions of dust accumu- lation rates, soil formation, weathering, wind intensity, and palaeovegetation (Zech et al., 2007; Gocke et al., 2014).

Moreover, LPSs provide occasional evidence of human activities. The regional Palaeolithic record includes openair sites such as at Dolní Věstonice (Tomášová, 1995; Antoine et al., 2013; Svoboda et al., 2015) and Pavlov (Svoboda, 1994; Adovasio et al., 1996; Fewlass et al., 2019), both in the Czech Republic, as well as the Lower Austrian sites of Willendorf (Nigst et al., 2008; Teyssandier and Zilhão, 2018; Zeeden and Hambach, 2021), Krems-Wachtberg (Händel et al., 2009, 2014; Terhorst et al., 2014), and KammernGrubgraben (Haesaerts and Damblon, 2016; NeugebauerMaresch et al., 2016; Händel et al., 2021).

Pleistocene sediment sequences were investigated in these areas predominantly with the aim of palaeoclimatic reconstructions but frequently independent of the archaeological background (Fink, 1954, 1962, 1976-1978; Terhorst et al., 2011, 2014; Meyer-Heintze et al., 2018; Sprafke et al., 2020). Studies using geochemical approaches have rarely been applied to archaeological sites, which makes comparisons with well-studied LPSs devoid of archaeological layers difficult. In many cases, this is also due to imprecise and/or contradictory age models. As a result of periglacial environmental conditions, palaeoclimatological and palaeoenvironmental records of the Last Glacial Maximum (LGM) from eastern and central Europe are frequently fragmentary and restricted regarding the choice of proxies (Kovács et al., 2012; Maier et al., 2021; Stojakowits et al., 2021). The LGM is defined here as the period with maximum global ice extent and therefore the lowest global sea levels. Consequently, we use the LGM definition sensu Lambeck et al. (2014) with 30$16.5 \mathrm{kacal} \mathrm{BP}$, being aware that other definitions exist (e.g. 23-19 ka cal BP, Mix et al., 2001; 26.5-19 ka cal BP, Clark et al., 2009; 27.5-23.3 ka cal BP, Hughes and Gibbard, 2015), and maximum glaciation varied geographically.

Sampling of sediment sequences with embedded archaeological context is a prerequisite for linking environmental variability to human occupation. Especially for the Upper 
Palaeolithic (Epigravettian) site of Kammern-Grubgraben, such combined studies are scarce (Haesaerts et al., 2016; Haesaerts and Damblon, 2016). Therefore, in this study we aim at (a) testing organic matter for radiocarbon dating, (b) evaluating proxies regarding their reliability for palaeoclimate research at archaeological sites, (c) shedding new light on palaeoclimate variability and palaeoenvironmental conditions during the LGM, and finally (d) placing the archaeological findings in an environmental context. From a longer perspective, this study helps in developing methodologies for linking local human activity with more comprehensive regional environmental records from adjacent LPSs using their geochemical and sedimentological signatures.

\section{Site description}

The Upper Palaeolithic open-air site of KammernGrubgraben $\left(48.48^{\circ} \mathrm{N}, 15.72^{\circ} \mathrm{E}\right.$; Fig. 1) is located in the municipality of Hadersdorf. The surrounding area is characterised by the partly loess-capped hills of the Bohemian Massif. Terracing was carried out in historical times for agri- and viniculture (Neugebauer-Maresch et al., 2016). The excavation site Kammern-Grubgraben is located in a trough-shaped valley sloping gently to the south between the hills of Heiligenstein in the west and Geißberg in the east (Fig. 1b). The area drains to the river Kamp, a tributary of the Danube. This setting seems to have been an attractive campsite for hunter-gatherers in an overall probably rather inhospitable environment.

Systematic archaeological and stratigraphic studies at Kammern-Grubgraben have been carried out since the 1980s (Urbanek, 1990; Brandtner, 1996; Montet-White, 1990; Haesaerts and Damblon, 2016; Haesaerts et al., 2016; Neugebauer-Maresch et al., 2016; Händel et al., 2021). These previous excavations (1985-1994) documented five succeeding archaeological layers (AL 1-5) attributed to at least five separate phases of occupation (Haesaerts et al., 2016; Neugebauer-Maresch et al., 2016). Humic horizons in the sedimentary context of AL 2-4 are reported by Haesaerts and Damblon (2016). Fieldwork was interrupted for about 20 years but recommenced in 2015. Preliminary results of recent investigations, however, suggest that only two main occupations are manifested in the archaeological horizons (AHs) AH 1 and AH 2 (Händel et al., 2021). AH 2 is characterised by complex structures made of stone slabs and densely accumulated artefacts, while the faint upper $\mathrm{AH} 1$ contains fewer finds (Montet-White, 1990; Händel et al., 2021). AH 2 is further described as a horizon representing a range of settlement activities including synoccupational reorganisation/restructuring as well as post-occupational disintegration processes (Händel et al., 2021). While AH 1 corresponds to the previous AL 1, AH 2 represents the former AL 2-4. Humic horizons in the context of AH 2 have not been traced in the new profiles. AL 5 has hitherto only been

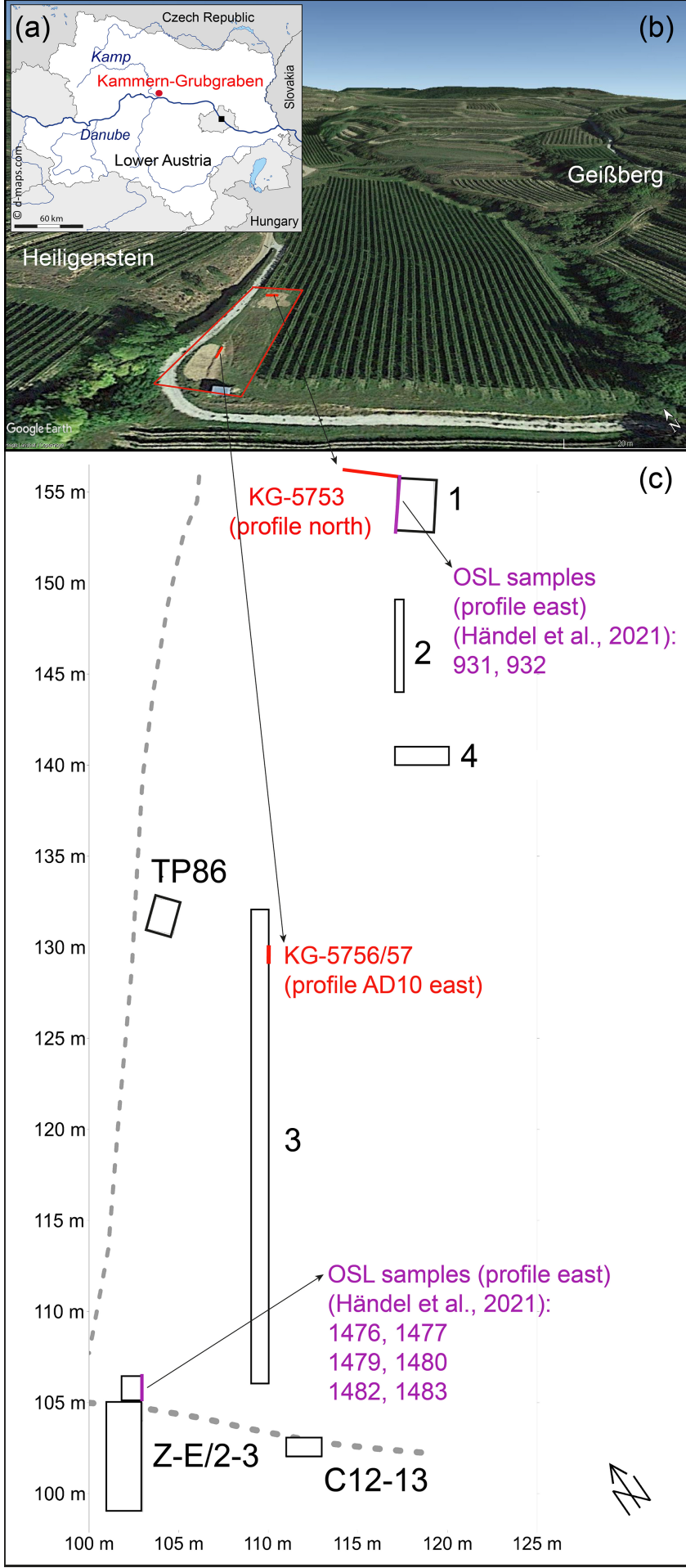

Figure 1. Overview of the study site Kammern-Grubgraben. (a) Map of Lower Austria with the study site Kammern-Grubgraben (map source: d-maps, 2021). (b) Aerial view (C Google Earth 2020) of the study site. The red polygon represents the excavation site, and the red lines show the locations of extracted loess sections. (c) Ground plan of the study site with exact locations (red lines) of the loess sections sampled in 2018 (local excavation grid) and the profiles with OSL samples (purple lines) published in Händel et al. (2021). 
found in a small area and can therefore not yet be contextualised from an archaeological perspective. The ${ }^{14} \mathrm{C}$ ages of mammal remains (bones and teeth) obtained from $\mathrm{AH} 1$ and 2 (AL 1-4) point at human activity between approximately 23-20 ka cal BP (Haesaerts et al., 2016; Händel et al., 2021), a time interval including Greenland Interstadials (GIs) GI2.1 and GI-2.2 (Rasmussen et al., 2014). Besides the mammal fauna (Logan, 1990; West, 1997), the gastropods of previous excavations were studied (Haesaerts, 1990; Frank and Rabeder, 1996, 1997; Frank, 2006).

Goals of the ongoing excavations are, among others, establishing the limits of the previous excavations, reassessment of the archaeological stratigraphy, and determining the site limits. The first results of these new investigations have recently been published (Händel et al., 2021). Of major importance for the study we present here is the stratigraphic connection between the area of previous excavations around trenches 1 and 2 and TP86 and the trenches in the southwest (Z-E/23 and C12-13), which document a far greater extent of the site than previously known (Fig. 1c). A stratigraphic connection was established by excavation of trench 3 , in which the main archaeological horizon $\mathrm{AH} 2$, with its pronounced stone structures, could be traced, while analyses of the lithic material confirmed cultural coherency of the artefact inventories, and chronometric results suggest contemporaneity (Händel et al., 2021). This forms the basis for the correlations of the profiles presented here (Fig. 2).

\section{Material and methods}

\subsection{Field sampling of loess profiles}

Two sections were sampled at the Upper Palaeolithic excavation site Kammern-Grubgraben (Fig. 1a, b) in 2018. The first section (KG-5753) is $91.3 \mathrm{~cm}$ long and was taken from the north profile in trench 1 . The other two overlapping sections KG-5756 and KG-5757 are 91.3 and $85.5 \mathrm{~cm}$ long, respectively, and come from profile AD10 east in trench 3 (Fig. 1c). Whereas AH 1 was only present in one section, AH 2 is documented in both analysed profiles (Fig. 2a, b).

The sediment sections were sampled in the field with the help of sheet steel profiles $(28 \times 27 \mathrm{~mm}, 0.6 \mathrm{~mm}$ thick, Knauf, Germany) with U-shaped cross-sections. Loess section KG-5753 starts $50 \mathrm{~cm}$ below the surface, and the 0$10 \mathrm{~cm}$ sampling depth contains the lower part of the modern soil, hereafter referred to as Anthrosol (Fig. 2a).

Loess sections KG-5757 and KG-5756 do not include the modern Anthrosol and were sampled with an overlap of $21.5 \mathrm{~cm}$ (Fig. 2b). Both sections were merged into a composite $155 \mathrm{~cm}$ long profile based on macroscopic and field observations as well as on geochemical records. The positions of loess sections within the excavation grid as well as absolute elevations ( $m$ a.s.l.) of their surface were determined by an electronic tachymeter.

\subsection{XRF core scanning and subsampling of loess sections}

With few exceptions (Liang et al., 2012; Sun et al., 2016), it has been common practice to carry out X-ray fluorescence (XRF) analyses of loess samples on discrete samples (Profe et al., 2018a; Profe and Ohlendorf, 2019) or to use a handheld scanner (Ward et al., 2018; Goff et al., 2020). In this study, sediment sections were analysed continuously in their sheet steel profiles. Prior to scanning, the sediment surfaces were thoroughly smoothened with a utility knife.

Sediment sections were photographically documented and analysed with an XRF core scanner (Itrax, Cox Analytical Systems, Sweden). Polarised light and a resolution of $500 \mathrm{dpi}$ were used for imaging. The recording resolution of XRF spectra was $1 \mathrm{~mm}$ and counting time $5 \mathrm{~s}$. A Cr tube was used at $30 \mathrm{kV}$ and $50 \mathrm{~mA}$. Repeated analyses on the same loess section revealed that only the most frequent elements $\mathrm{Si}, \mathrm{K}, \mathrm{Ca}, \mathrm{Ti}$, and $\mathrm{Fe}$ provide reproducible results. The element counts were standardised using the centred logratio (clr) transformation (Aitchison, 1982; Martin-Puertas et al., 2017). This transformation accounts for matrix effects caused by, for example, variations in grain size or water and organic matter contents and approximates true element concentrations (Weltje et al., 2015).

After scanning, the sections were continuously subsampled at a $1 \mathrm{~cm}$ resolution. This resulted in a total of 92 (KG5753, KG-5756) and 85 (KG-5757) samples. Each sample represented a volume of ca. $7 \mathrm{~cm}^{3}$, which is equivalent to about $10 \mathrm{~g}$. Samples were suspended in deionised water and thereafter lyophilised for further analytical procedures. This treatment allowed dispersion of the dried sediment without mechanical force, preventing the destruction of microfossils. After drying, each sample was subdivided into three fractions for grain-size analyses $(0.5 \mathrm{~g})$, isotope-geochemical analyses $(0.65 \mathrm{~g})$, and sieving for microfossils $(5-8 \mathrm{~g})$.

\subsection{Grain-size analyses}

Grain-size distribution was determined for every fifth centimetre, using a laser particle analyser (LS 200, Beckman Coulter). Samples were sieved to $\leq 2 \mathrm{~mm}$. For each of the selected samples, $0.5 \mathrm{~g}$ was weighed into centrifuge tubes and left overnight with $1 \mathrm{~mL}$ of $30 \% \mathrm{H}_{2} \mathrm{O}_{2}$ to destroy organic matter. Afterwards, the tubes were placed in a drying cabinet at $105^{\circ} \mathrm{C}$ for $2 \mathrm{~h}$. To dissolve secondary carbonates, $2.4 \mathrm{~mL}$ of $10 \% \mathrm{HCl}$ was added to each sample, which was placed in a drying cabinet at $85^{\circ} \mathrm{C}$ for $4 \mathrm{~min}$. Afterwards, the samples were washed with deionised water and centrifuged until a pH of 4.5 was reached. Subsequently, $24 \mathrm{~mL}$ of $2 \mathrm{M} \mathrm{NaOH}$ was added to each tube and left in a drying cabinet at $85^{\circ} \mathrm{C}$ for $5 \mathrm{~min}$. Samples were washed with deionised water and centrifuged until a $\mathrm{pH}$ of 8 was reached. Then, to lower the $\mathrm{pH}$ to 7 , a drop of $5 \% \mathrm{HCl}$ was added, and samples were washed and centrifuged again. Subsequently, samples were 
(a)

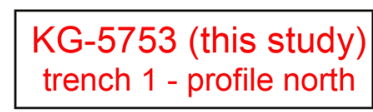

Radiocarbon Stratigraphy samples

Ground level at

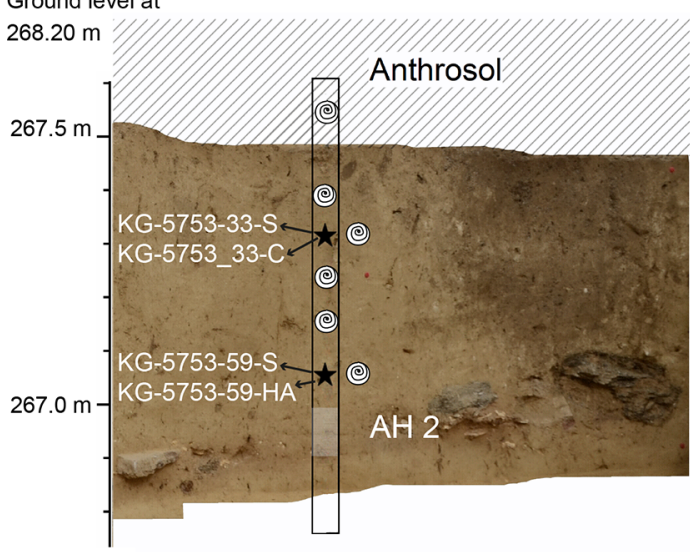

(b)
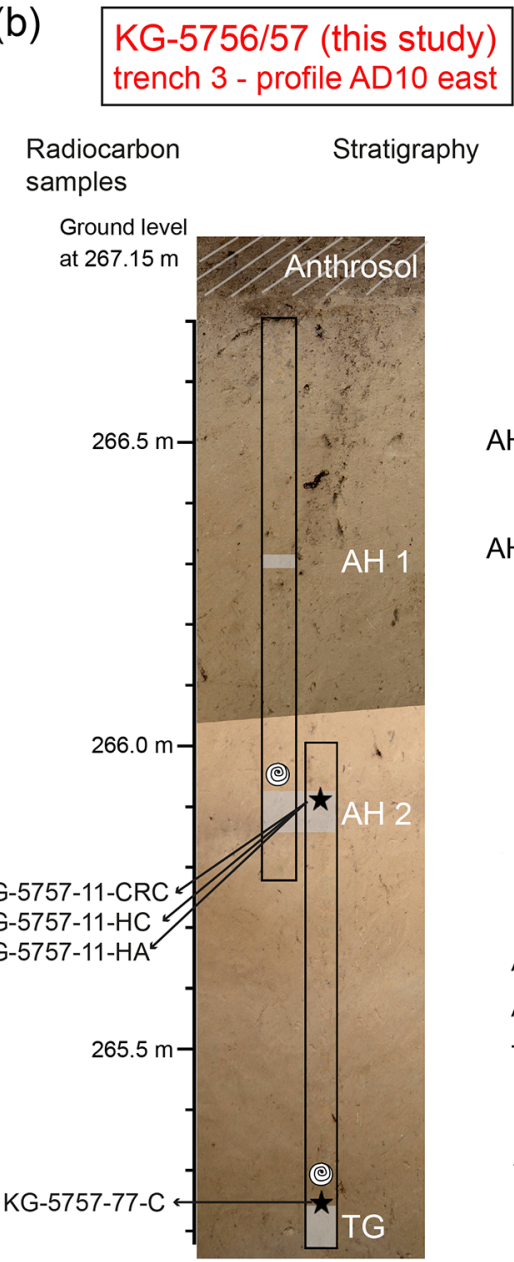

tratigraphy

\section{ol}

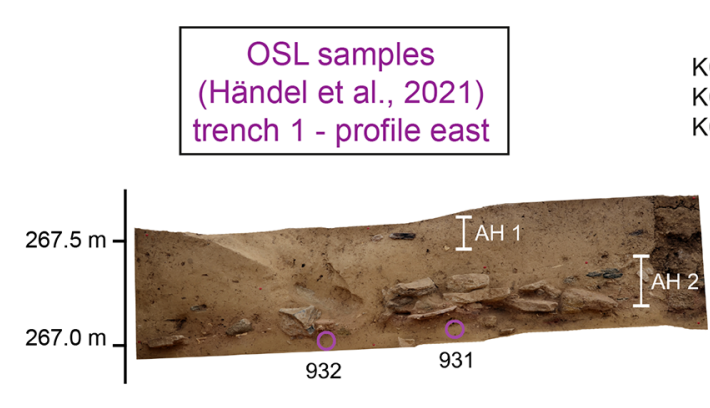

OSL samples

(Händel et al., 2021)

trench 1 - profile east

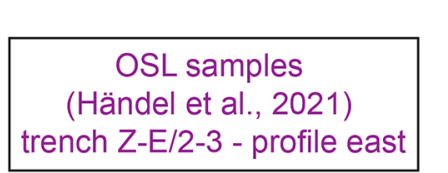

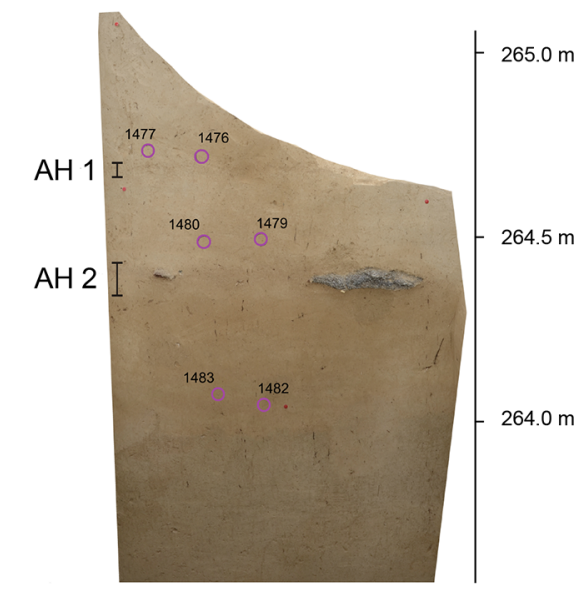

\section{Legend}

$\begin{array}{ll}\text { AH } 1 & \text { archaeological horizon } 1 \\ \text { AH } 2 & \text { archaeological horizon } 2 \\ \text { TG } & \text { tundra gley } \\ \text { (C) } & \text { gastropods } \\ & \\ \text { radiocarbon sample: } & -S=\text { snail, }-\mathrm{C}=\text { charcoal, } \\ & -\mathrm{HA}=\text { humic acids, } \\ & -\mathrm{CRC}=\text { calcified root cells, } \\ & -\mathrm{HC}=\text { hypocoatings } \\ \text { OSL sample }\end{array}$

Figure 2. Orthophotographs of excavation profiles with projected positions of (a) loess profile KG-5753 - profile north in trench 1 and OSL samples $(932,931)$ taken from profile east in trench 1 (Händel et al., 2021), (b) KG-5756 (upper part) and KG-5757 (lower part) from profile AD10 east in trench 3, and (c) OSL samples $(1482,1483,1479,1480,1476$, and 1477) taken from profile east in trench Z-E/2-3 (Händel et al., 2021). Hatched areas represent the modern Anthrosol. Archaeological horizons (AH 1 and AH 2) as well as the underlying tundra gley (TG) in KG-5757 are shaded. Stratigraphic positions of gastropods are given for both loess profiles.

mixed with $\left(\mathrm{NaPO}_{3}\right)_{n}$ and $\mathrm{NaCO}_{3}$ and left on a rotator for $8 \mathrm{~h}$ for dispersion.

Each sample was analysed in at least three runs to eliminate possible outliers and to check for reproducibility. The first run was taken as a test run. Results were calculated from runs two and three. Results of laser particle analyses were processed with GRADISTAT (Blott and Pye, 2001). Only for the median grain size were the raw data used. Grain sizes were classified according to standard size classes: coarse sand $(\mathrm{cS}, 630-2000 \mu \mathrm{m})$, middle sand $(\mathrm{mS}, 200-630 \mu \mathrm{m})$,

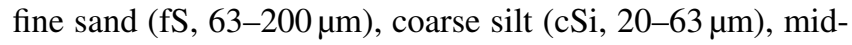
dle silt ( $\mathrm{mSi}, 6.3-20 \mu \mathrm{m})$, fine silt (fSi, $2-6.3 \mu \mathrm{m}$ ), and clay (cl, $<2 \mu \mathrm{m})$. Grain-size indices $(20-50 \mu \mathrm{m} /<20 \mu \mathrm{m})$ and $U$ ratios $(16-44 \mu \mathrm{m} / 5.5-16 \mu \mathrm{m})$ were determined using the size fractions according to Rousseau et al. (2002) and Vanderberghe et al. (1997), respectively.

\subsection{Geochemical analyses}

Carbon $(\mathrm{C})$ and nitrogen $(\mathrm{N})$ contents were analysed for every centimetre with a $\mathrm{CN}$ analyser (vario EL cube, Elementar Analysensysteme GmbH, Germany). For each lyophilised sample, $500 \mathrm{mg}$ was homogenised with a mortar and a pestle. Macroscopic remains were removed prior to homogenisation. For determination of total carbon (TC) and total nitrogen (TN), $20 \mathrm{mg}$ was weighed in tin capsules and analysed in the $\mathrm{CN}$ analyser. The samples were measured twice to check reproducibility. To estimate total inorganic carbon (TIC), another fraction of each sample was dried at $105^{\circ} \mathrm{C}$ overnight. Thereafter, $400 \mathrm{mg}$ of each sample was weighed in porcelain crucibles and put in a muffle furnace at $550^{\circ} \mathrm{C}$ for $4 \mathrm{~h}$ to remove total organic carbon (TOC) (Heiri et al., 2001). After this high-temperature heating, samples were weighed 


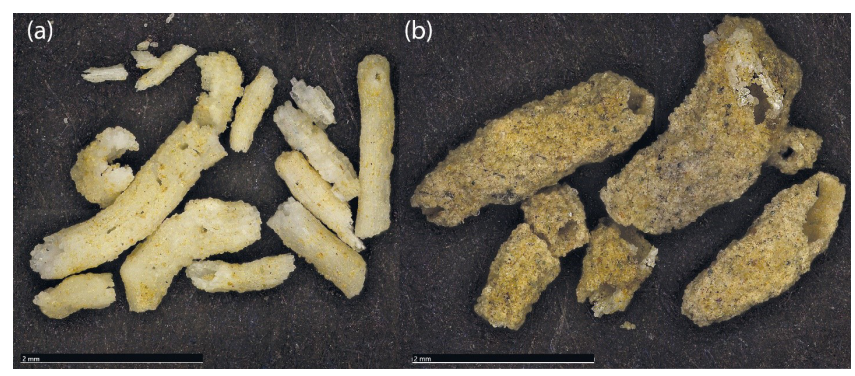

Figure 3. Photographs of examples of (a) CRC (KG-5756, $30 \mathrm{~cm}$ depth) and (b) $\mathrm{HC}$ (KG-5756, $60 \mathrm{~cm}$ ). The scales are $2 \mathrm{~mm}$ each.

again for the $\mathrm{CN}$ analyser to analyse TIC. TOC was calculated as the difference between TC and TIC, corrected for the weight loss from loss on ignition (LOI). Assuming that TIC is present as $\mathrm{CaCO}_{3}$, the carbonate content of the samples was calculated from TIC using a stoichiometric factor of 8.33. All data are given in per cent $(\%)$ of dry mass.

\subsection{Pedogenic carbonates}

Remaining after previous analyses, $5-8 \mathrm{~g}$ of the lyophilised bulk sediment was sieved with a $500 \mu \mathrm{m}$ mesh to separate coarse particles and secondary (pedogenic) carbonates from every centimetre sample. The coarse particles were screened under a microscope, and microscale secondary carbonates were characterised following the criteria of Barta (2011). They generally comprise calcified root cells (CRC), hypocoatings (HC), carbonate coatings (CC), earthworm biospheroids (EBS), and needle-fibre calcites (NFC). CRC are identifiable by elongated calcite crystals that form tubes of up to $1 \mathrm{~cm}$ in length and are of bright whitish to light brownish colour, the latter representing the decalcified margin (Becze-Deák et al., 1997; Barta, 2011). HC on the other hand are pore walls of the soil matrix impregnated with $\mathrm{CaCO}_{3}$ (Barta, 2011). They consist of micritic or small calcite tubes mixed with other minerals such as mica (Becze-Deák et al., 1997; Barta, 2011, 2014). Their cylindrical and branched shape is of 1-6 mm length and 3-4 mm width on average (Barta, 2014). In this study, only CRC and $\mathrm{HC}$ were present in the sediment (up to $66 \mathrm{mg} \mathrm{HC}$ per gram of sediment in $46-47 \mathrm{~cm}$ depth in KG-5753). They were handpicked, separated, and documented using the extendeddepth-of-field option of a digital reflected-light microscope (Smartzoom 5, Carl Zeiss Microscopy GmbH, Germany) (Fig. 3).

\subsection{Stable isotope analyses}

Secondary carbonate concretions were not evenly distributed in the sediment cores. In total, 56, 74, and 26 (88, 92, and 75) samples of the KG-5753, KG-5756, and KG-5757 sections, respectively, contained sufficient CRC (HC) for isotope analyses. CRC (70-150 $\mu \mathrm{g})$ and HC (150-200 $\mu \mathrm{g})$ were crushed with a pestle and weighed into borosilicate-glass septum vials using a microbalance (Sartorius, ME36S, Germany). Carbonates reacted with concentrated, water-free phosphoric acid in the previously helium-flushed septum vial. After at least $3 \mathrm{~h}$ of equilibration at constantly $70^{\circ} \mathrm{C}$ in a heating block, the evolved $\mathrm{CO}_{2}$ gas was transferred via a GasBench II (Thermo Fisher, USA) coupled to an isotope-ratio mass spectrometer (IRMS) (Delta V Advantage, Thermo Fisher, USA) for carbon $\left(\delta^{13} \mathrm{C}\right)$ and oxygen $\left(\delta^{18} \mathrm{O}\right)$ stable isotope analyses.

For the measurement of $\delta^{13} \mathrm{C}_{\mathrm{org}}$, bulk sediment samples were decalcified following the method of Pötter et al. (2020). Of each sample, $150 \mathrm{mg}$ was weighed into centrifuge tubes, treated with $25 \mathrm{~mL}$ of hydrochloric acid $(\mathrm{HCl}, 5 \%)$, and kept in a water bath at $50^{\circ} \mathrm{C}$ for $4 \mathrm{~h}$. Subsequently, samples were washed with deionised water by repeated centrifugation. After the removal of $\mathrm{HCl}$, samples were lyophilised. For stable isotope analysis, a sample amount equivalent to $50-300 \mu \mathrm{g}$ of organic carbon (2-40 mg dry matter) was weighed into tin capsules. Samples were combusted at $1080^{\circ} \mathrm{C}$ in an elemental analyser (EA) (NC 2500, Carlo Erba, Italy) coupled to an isotope-ratio mass spectrometer (IRMS) (DeltaPlus, Thermo Finnigan, Germany) used for isotope analyses.

All results are expressed as delta $(\delta)$ values in per mil $(\% o)$ relative to international standards.

The $\delta$ notation is defined as

$\delta=\left(R_{\text {Sample }} / R_{\text {Standard }}-1\right)$,

where $R$ is the mass ratio of the heavier isotope to the lighter isotope (e.g. ${ }^{13} \mathrm{C} /{ }^{12} \mathrm{C}$ or ${ }^{18} \mathrm{O} /{ }^{16} \mathrm{O}$ ) of the sample and an international standard (Vienna Pee Dee Belemnite (VPDB) for carbon, Vienna Standard Mean Ocean Water (VSMOW) for oxygen). The international standards NBS 18 and NBS 19 (Brand et al., 2014) and a laboratory standard consisting of pure Solnhofen limestone ("Pfeil"; Oehlerich et al., 2013) were used to calibrate the stable isotope analyses of secondary carbonates. For stable isotope analyses of bulk organic carbon, the international standards IAEA-CH-7 and USGS41 (Brand et al., 2014) and a laboratory standard ("Peptone"; Mayr et al., 2017a) were used.

\subsection{Radiocarbon dating}

Loess sequences are commonly dated with luminescence (Thiel et al., 2011a; Veres et al., 2018) or radiocarbon techniques (Újvári et al., 2014; Haesaerts et al., 2016). At the studied site of Kammern-Grubgraben, published radiocarbon measurements are only available for bone material from the archaeological layers and reveal ages around 23-22 ka cal BP (Haesaerts et al., 2016; Händel et al., 2021). Thus, additional ${ }^{14} \mathrm{C}$ measurements were carried out in order to place the loess sections into a more precise timeframe. However, suitable materials (charcoal, bones) are barely available outside of the well-dated archaeological horizons. Therefore, radiocarbon age determination was tested on gastropods, humic acid fractions, and secondary pedogenic carbonates. The weights 
of the respective samples are listed in Table 1. Gastropods (mainly the species Vallonia costata) were handpicked after sieving with a $500 \mu \mathrm{m}$ mesh to separate coarse particles from bulk sediment. Almost all gastropods were fragmented and allowed identification only to the genus level, except for a few specimens which had a well-preserved aperture allowing species identification. Only two gastropods provided a sufficient mass (1.6 mg each) for radiocarbon dating.

All these materials have been previously tested at other loess sites with some success (e.g. Pustovoytov and Terhorst, 2004; Gocke et al., 2011; Xu et al., 2011; Wang et al., 2014; Újvári et al., 2016a). If possible, different sample pairs (Fig. 2) from the same depths were handpicked under a binocular microscope, thoroughly cleaned with distilled water, dried, and then sent to the Poznan Radiocarbon Laboratory (Poland) for radiocarbon accelerator mass spectrometry (AMS) measurements. Gastropod shell samples were rinsed with $\mathrm{HCl}$ and $\mathrm{H}_{2} \mathrm{O}_{2}$ prior to radiocarbon measurement. However, due to the small sample size, there was no control on the amount of material removed during these steps. The residues of these samples were then leached using $\mathrm{H}_{3} \mathrm{PO}_{4}$, resulting in very small portions of available carbon. The IntCal20 curve (Reimer et al., 2020) and CALIB 8.2 (Stuiver et al., 2020) were used for calibration of radiocarbon ages. Note that for reasons of comparability with the new radiocarbon ages presented here, all ages are given as calibrated kiloyears (ka cal BP) although other dating methods were partly used.

\section{Results}

\subsection{Sediment description and grain-size distribution}

Based on sedimentary features like colour, amount of carbonate concretions, rooting, and aggregate texture, the sections were subdivided into different units separated by archaeological horizons and the basal tundra gley. These units are overlain by an Anthrosol in both sections, which was sampled only in KG-5753 (Fig. 2a). This Anthrosol is a disturbed and machine-worked vineyard soil, which shows characteristic soil features such as roots and an aggregate texture. It further appears much darker than the rest of the section. The next unit consists of lighter-coloured loess sediment, which contains some root remains. High amounts of secondary carbonates are present from 11 to $24 \mathrm{~cm}$ depth and again from 40 to $45 \mathrm{~cm}$ depth and around AH 2 . With increasing depth, the sediment becomes slightly darker. Rock fragments of 1-5 mm diameter are present around $\mathrm{AH} \mathrm{2,} \mathrm{corresponding}$ to the lateral presence of up to decimetre-sized boulders in AH 2 (Fig. 2a). Profile KG-5756-KG-5757 (hereafter KG5756/57) starts immediately below the modern Anthrosol (Fig. 2b). The upper part contains carbonate concretions and is equivalent to the loess above AH 2 in KG-5753. The position of AH 1 was estimated from adjacent sections, as the sediment is hardly distinguishable from the surrounding substrate in KG-5756. AH 2 contains rock fragments and arte- facts in KG-5756/57 and serves as the tie point for merging both sub-profiles with an overlap of about $21 \mathrm{~cm}$. AH 2 contains the highest amount of secondary carbonates (CRC and HC) in KG-5756/57. The unit below AH 2 consists of more homogenous loess almost without CRC but with occasional root traces. Field observations suggest that the slightly bleached horizon at the base of KG-5757 (in the lowermost $15 \mathrm{~cm}$ ) represents a tundra-gley soil. In the present study, terrestrial gastropods (Vallonia costata and Pupilla sp.) were found only in very small numbers and often only as shell fragments (Fig. 2a, b).

The grain-size analyses of KG-5753 and KG-5756/57 show a dominance of silt in all measured samples, while cS is practically absent in all profiles (Fig. 4). The profile KG5753 contains between $7.9 \%$ and $8.8 \% \mathrm{cl}$. fSi has a similar distribution to $\mathrm{mSi}$, although an overall lower content is evident. MSi increases slowly from $15 \%$ at $90 \mathrm{~cm}$ depth to $20.0 \%$ at $10 \mathrm{~cm}$. cSi varies between $49 \%$ and $41 \%$ from 75 to $10 \mathrm{~cm}$ depth. The fS content decreases from $34.5 \%$ at $90 \mathrm{~cm}$ depth to $24.4 \%$ at the top. The $\mathrm{mS}$ content reaches up to $5.0 \%$ at the bottom of the profile and shows the highest content of $9.5 \%$ at the top, i.e. the Anthrosol. The grain-size index and $U$ ratio show a decreasing trend from bottom to top with a slight decrease in $\mathrm{AH} 2$.

In KG-5756/57, the clay content slightly decreases from the bottom of the profile to $100 \mathrm{~cm}$ depth and then shows a small but steady increase from $100 \mathrm{~cm}$ depth to the top (Fig. 4b). The sand fraction slightly decreases from bottom to top. The $\mathrm{fS}$ fraction is most prominent at $101 \mathrm{~cm}$ depth, and then again between 70 and $50 \mathrm{~cm}$ depth. An increase in $\mathrm{mS}$ is present between 110 and $90 \mathrm{~cm}$ depth and again from 65 to $50 \mathrm{~cm}$ depth. Thus, the $\mathrm{mS}$ fraction is dominant below and above the archaeological layer located between 88 and $78 \mathrm{~cm}$ depth. Both $\mathrm{fS}$ and $\mathrm{mS}$ are highest at $100 \mathrm{~cm}$ depth. The $U$ ratio ranges from 2.0 to 2.7 and the grain-size index from 1.0 to 1.4. Low values occur in the tundra gley and at the top of the profile; maximum values are between $110-95 \mathrm{~cm}$. In the archaeological horizons (AH 2, AH 1) local minima of the $U$ ratio as well as the grain-size index are visible.

\subsection{Geochemistry}

\subsubsection{Organic geochemistry}

The TOC content of profile KG-5753 is $<1 \%$ except in the upper $12 \mathrm{~cm}$, in which TOC increases from $1.3 \%$ to $3.4 \%$, reflecting the Anthrosol (Fig. 5a). The $\delta^{13} \mathrm{C}_{\text {org }}$ values range from $-28.4 \%$ o to $-23.7 \%$. The TOC content of the merged profile KG-5756/57 ranges from $0.2 \%$ to $0.6 \%$, showing minima between 107 and $105 \mathrm{~cm}$ depth, at 91, 86, 67, 37, and $16-13 \mathrm{~cm}$ depth (Fig. 5b). Maxima are recognisable at 151 and at $119 \mathrm{~cm}$ depth. The lowest $\delta^{13} \mathrm{C}_{\text {org }}$ value is $-28.3 \%$ o (in KG-5757, $90 \mathrm{~cm}$ depth) and the highest $-23.9 \%$ (in KG$5756,92 \mathrm{~cm}$ depth).

Although the $\mathrm{C} / \mathrm{N}$ ratios of both profiles must be considered with caution since $\mathrm{TN}$ contents are close to the detection 
Table 1. Radiocarbon ages of different materials. Stratigraphically consistent ages are indicated in bold.

\begin{tabular}{|c|c|c|c|c|c|c|}
\hline Sample ID & Lab no. & $\begin{array}{r}\text { Sampling } \\
\text { depth } \\
(\mathrm{cm})\end{array}$ & $\begin{array}{l}\text { Uncalibrated } \\
\text { radiocarbon date } \\
(\mathrm{BP} \pm \text { analytical error })\end{array}$ & $\begin{array}{l}\text { Calibrated age range } \\
(\text { cal BP and } \\
\text { probabilities }(2 \sigma))\end{array}$ & Material & $\begin{array}{r}\text { Weight } \\
(\mathrm{mg})\end{array}$ \\
\hline \multirow[t]{2}{*}{ KG-5753-33-S } & \multirow[t]{2}{*}{ Poz-128063 } & \multirow[t]{2}{*}{33} & \multirow[t]{2}{*}{$12390 \pm 170$} & $15160-14020(0.999)$ & \multirow{2}{*}{$\begin{array}{l}\text { Terrestrial gastropod } \\
\text { (Vallonia costata) }\end{array}$} & \multirow[t]{2}{*}{1.6} \\
\hline & & & & $13900(0.001)$ & & \\
\hline KG-5753-33-C & Poz-128202 & 33 & $117.23 \pm 1.33 \mathrm{pMC}$ & Younger than $1950 \mathrm{CE}$ & Recent root & 2.77 \\
\hline \multirow[t]{2}{*}{ KG-5753-59-S } & \multirow[t]{2}{*}{ Poz-128064 } & \multirow[t]{2}{*}{59} & \multirow{2}{*}{$9960 \pm 100$} & $11760-11210(0.983)$ & \multirow{2}{*}{$\begin{array}{l}\text { Terrestrial gastropod } \\
\text { (Vallonia costata) }\end{array}$} & \multirow[t]{2}{*}{1.6} \\
\hline & & & & $11810-11790(0.017)$ & & \\
\hline \multirow[t]{2}{*}{ KG-5753-59-HA } & \multirow[t]{2}{*}{ Poz-128200 } & \multirow[t]{2}{*}{59} & \multirow[t]{2}{*}{$5060 \pm 80$} & $5940-5600(0.997)$ & \multirow[t]{2}{*}{ Humic acids } & \multirow[t]{2}{*}{2998.6} \\
\hline & & & & $5980(0.003)$ & & \\
\hline \multirow[t]{2}{*}{ KG-5757-11-CRC } & \multirow[t]{2}{*}{ Poz-128065 } & \multirow[t]{2}{*}{79} & \multirow[t]{2}{*}{$2305 \pm 30$} & $2360-2300(0.778)$ & \multirow{2}{*}{$\begin{array}{l}\text { Rhizoconcretions } \\
\text { (CRC) }\end{array}$} & \multirow[t]{2}{*}{14.2} \\
\hline & & & & $2230-2180(0.222)$ & & \\
\hline \multirow[t]{4}{*}{ KG-5757-11-HC } & \multirow{4}{*}{ Poz-128067 } & \multirow[t]{4}{*}{79} & \multirow{4}{*}{$5000 \pm 40$} & $5860-5810(0.291)$ & \multirow{4}{*}{$\begin{array}{l}\text { Rhizoconcretions } \\
\text { (HC) }\end{array}$} & \multirow[t]{4}{*}{12.8} \\
\hline & & & & $5790(0.009)$ & & \\
\hline & & & & $5770-5650(0.608)$ & & \\
\hline & & & & $5640-5600(0.092)$ & & \\
\hline \multirow[t]{3}{*}{ KG-5757-11-HA } & \multirow[t]{3}{*}{ Poz-128201 } & \multirow[t]{3}{*}{79} & \multirow[t]{3}{*}{$2860 \pm 40$} & $3080-2860(0.961)$ & \multirow[t]{3}{*}{ Humic acids } & \multirow[t]{3}{*}{3086.7} \\
\hline & & & & $3110-3100(0.017)$ & & \\
\hline & & & & $3140-3130(0.021)$ & & \\
\hline KG-5757-77-C & Poz-128204 & 145 & $24240 \pm 240$ & $28930-27830$ & Charcoal & 1.0 \\
\hline
\end{tabular}
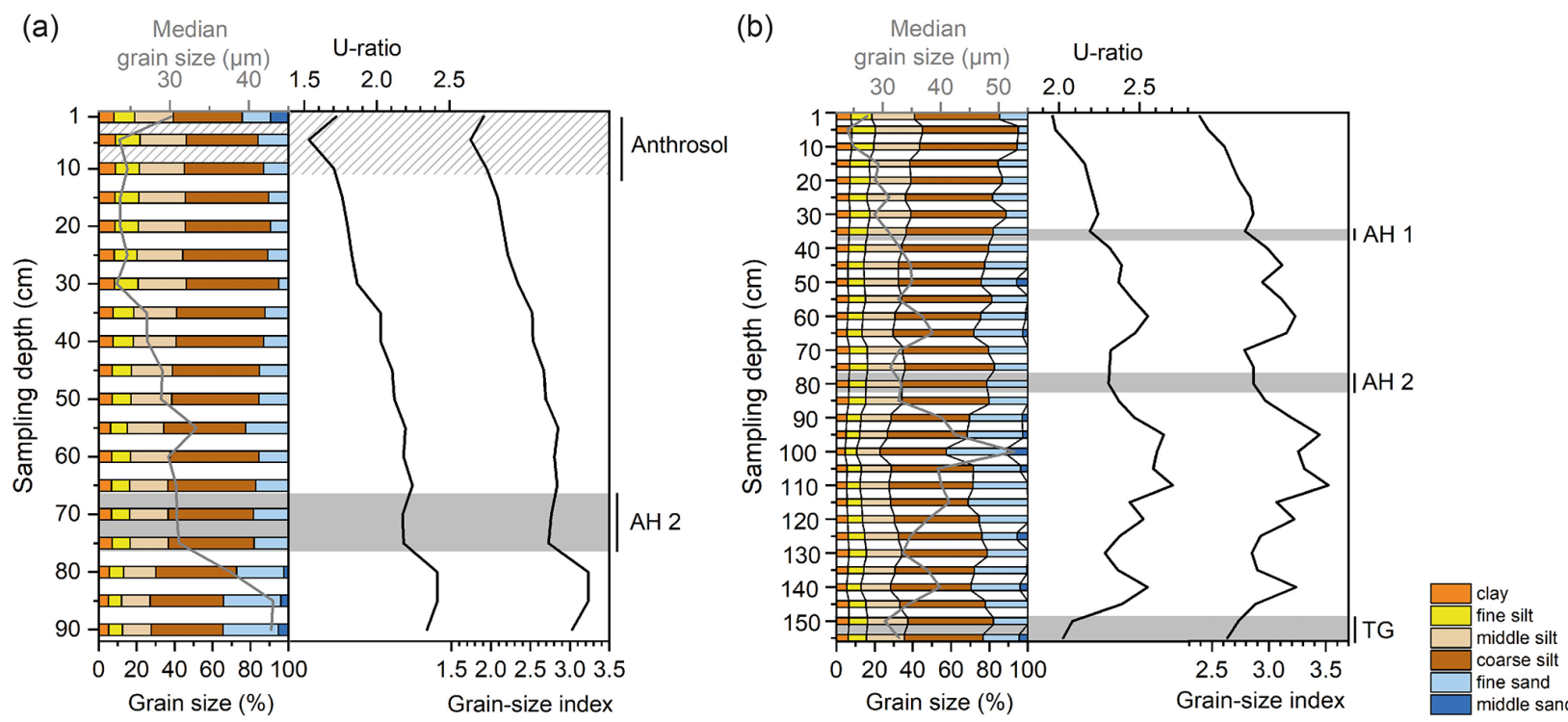

Figure 4. Grain-size distribution, median grain size, $U$ ratio $(16-44 \mu \mathrm{m} / 5.5-16 \mu \mathrm{m})$, and grain-size index $(20-50 \mu \mathrm{m} /<20 \mu \mathrm{m})$ of $(\mathbf{a}) \mathrm{KG}-$ 5753 and (b) KG-5756/57. Grain sizes are classified according to standard size classes with coarse sand (cS, 630-2000 $\mu \mathrm{m})$, medium sand

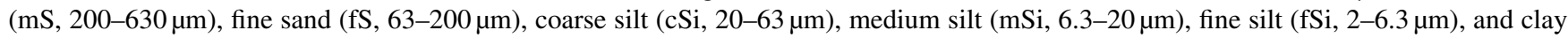
$(\mathrm{cl},<2 \mu \mathrm{m})$. The hatched area in (a) represents the base of the sampled Anthrosol; shaded areas represent the archaeological horizons (AH 1 and $\mathrm{AH} 2$ ) and the tundra gley (TG). 
(a)

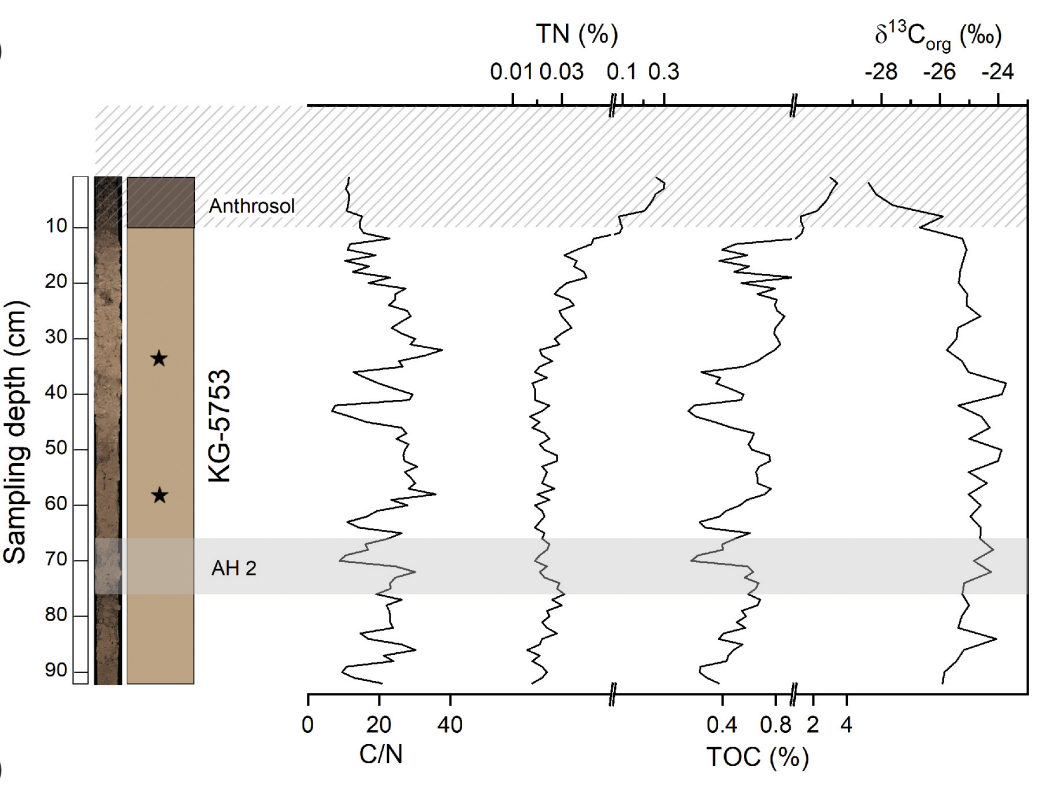

(b)

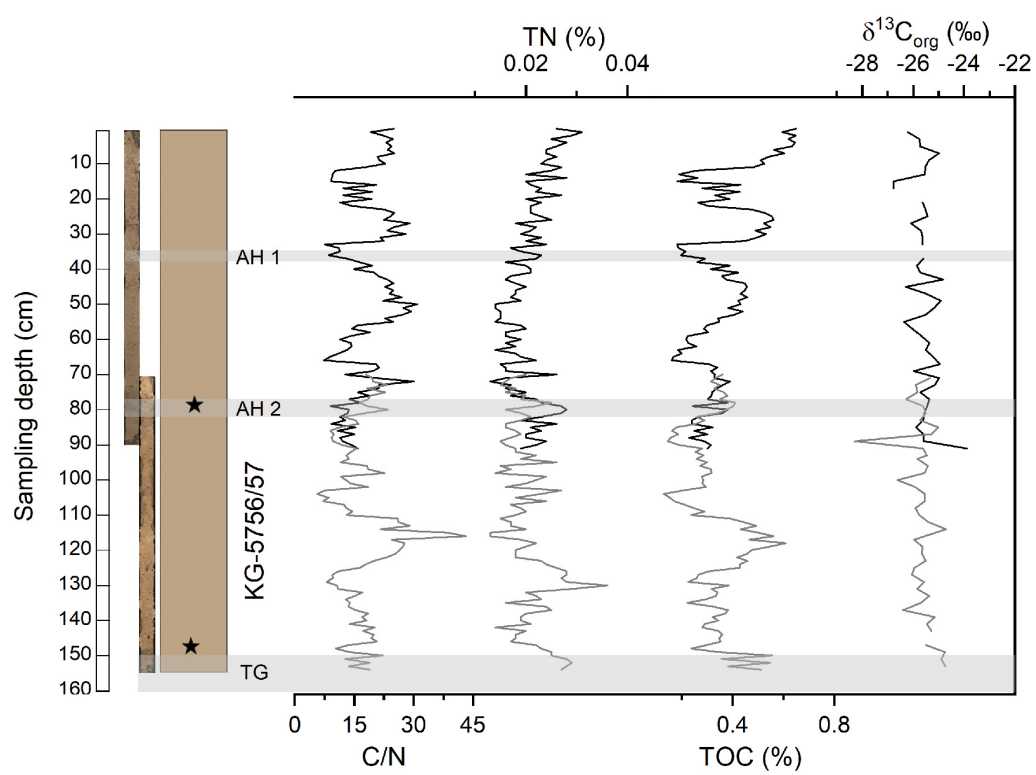

Figure 5. Organic geochemistry including $\mathrm{C} / \mathrm{N}$ (carbon-to-nitrogen ratio), TN (total nitrogen), TOC (total organic carbon), and $\delta^{13} \mathrm{C}_{\text {org }}$ (organic carbon isotope ratio) of (a) KG-5753 and (b) KG-5756/57. The hatched area in (a) represents the base of the sampled Anthrosol; shaded areas represent the archaeological horizons (AH 1 and $\mathrm{AH}$ 2) and the tundra gley (TG). Black stars symbolise the positions of radiocarbon samples. Missing values are indicated by gaps. Note axis breaks and scale changes in (a) for TN and TOC.

limit for all profiles (maximum values of $0.3 \%$ and $0.03 \%$ in KG-5753 and KG-5756/57, respectively), they show a comparable range and similar variations, pointing to environmental control of $\mathrm{C} / \mathrm{N}$ variations.

\subsubsection{Inorganic geochemistry}

The $\mathrm{CaCO}_{3}$ content in KG-5753 shows an increase from the bottom to $45 \mathrm{~cm}$ depth and a decrease from $37 \%$ to $25 \%$ between 15 and $10 \mathrm{~cm}$ depth (Fig. 6a). As an overall pattern the $\mathrm{CaCO}_{3}$ content of KG-5756/57 slightly increases from bot- tom to top with values ranging from $23.1 \%$ at $147 \mathrm{~cm}$ depth to $32.7 \%$ at $129 \mathrm{~cm}$ depth. A minimum of $22.6 \%$ is evident at $101 \mathrm{~cm}$ depth, followed by a further increase to $41.2 \%$ at $13 \mathrm{~cm}$ depth (Fig. 6b).

XRF-core-scanning analyses provided results for the elements $\mathrm{Cr}, \mathrm{K}, \mathrm{Mn}, \mathrm{Zn}, \mathrm{Sr}, \mathrm{Ca}, \mathrm{Si}, \mathrm{Ti}, \mathrm{Fe}$, and Rb. However, only $\mathrm{Ca}, \mathrm{K}, \mathrm{Si}, \mathrm{Ti}$, and $\mathrm{Fe}$ exhibited high signal-to-noise ratios and are therefore considered for further discussion.

The influence of the topsoil explains the higher variability in analysed elements above a depth of $13 \mathrm{~cm}$ in KG-5753 (Fig. 6a). Aside from that, the variations in $\mathrm{Fe}$ and $\mathrm{Ti}$ are in- 
(a)

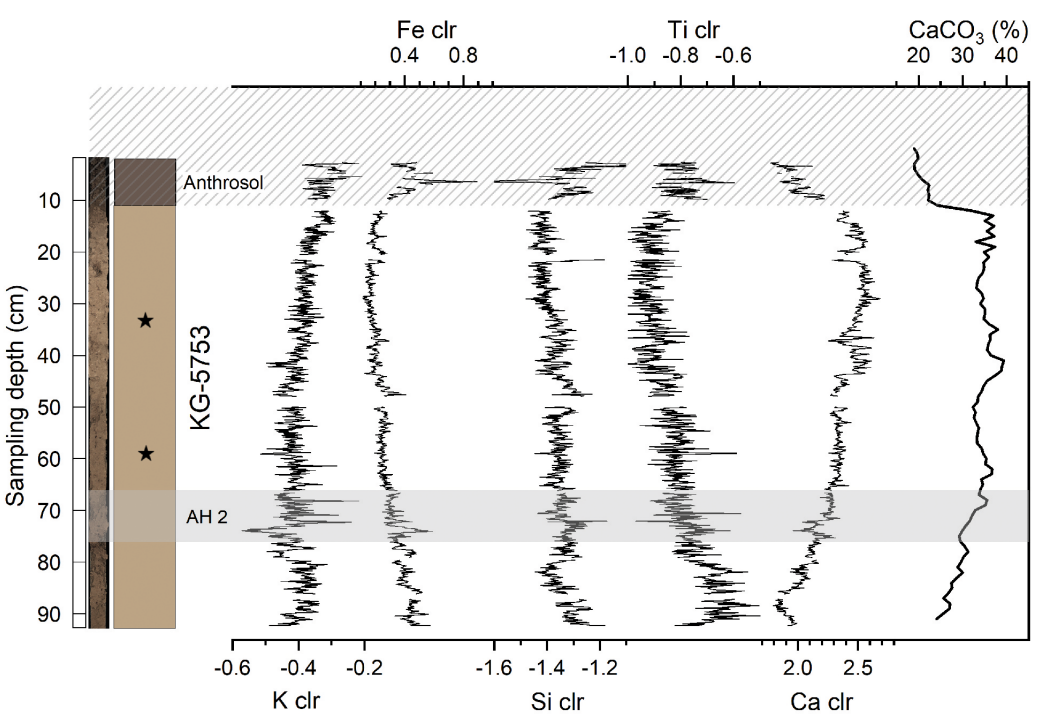

(b)

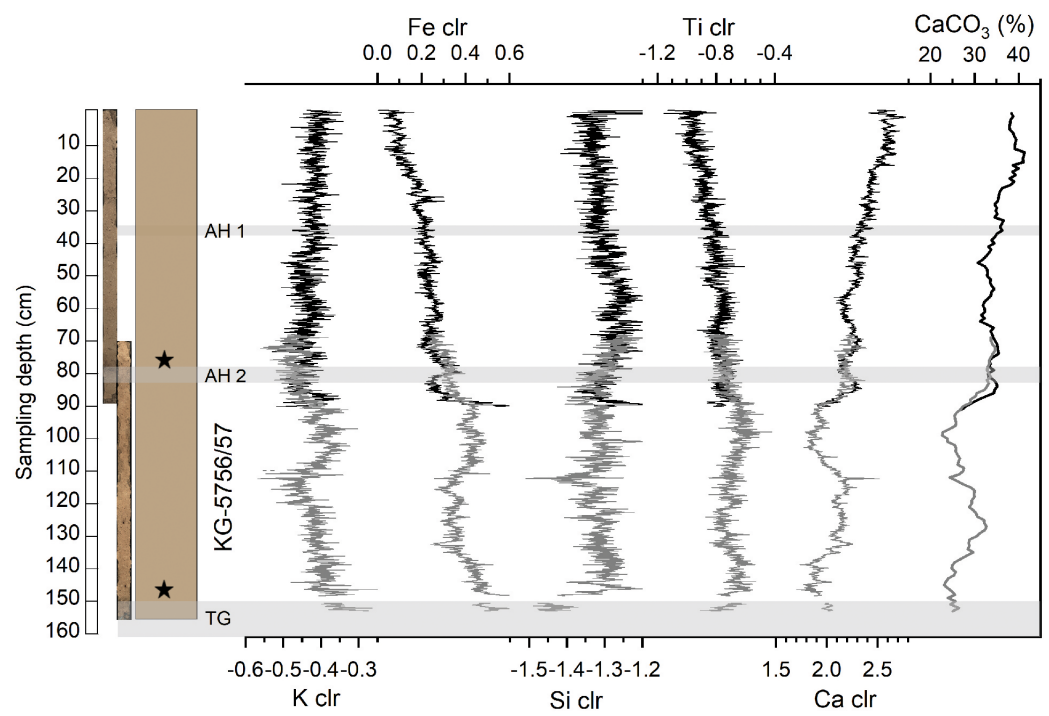

Figure 6. Element and $\mathrm{CaCO}_{3}$ contents of (a) KG-5753 and (b) KG-5756/57. Hatched area in (a) represents the base of the sampled Anthrosol, shaded areas the archaeological horizons (AH 1 and AH 2) and the tundra gley (TG). Black stars symbolise the positions of radiocarbon samples. Missing values are indicated by gaps. For element contents derived from XRF-scanning analyses, clr-transformation was applied to account for matrix effects.

versely correlated to $\mathrm{Ca}\left(R^{2}\right.$ is 0.83 and 0.67 , respectively, in KG-5753, and $R^{2}$ is 0.89 and 0.80 , respectively, in KG5756/57), the element with the highest counts of the records. The comparison with $\mathrm{CaCO}_{3}$ analyses shows that $\mathrm{Ca}$ is predominantly bound to carbonates (Fig. 6a, b). Thus, Fe and Ti variations are presumably the result of dilution caused by varying carbonate amounts. In contrast to $\mathrm{Fe}$ and $\mathrm{Ti}$, the overall trends in $\mathrm{K}$ and $\mathrm{Si}$ are not antagonistic to $\mathrm{Ca}$, but the variability in these elements is rather low.

The distribution of $\mathrm{Ca}$, however, shows a different pattern, as there is an increasing trend from bottom to top. Within this increase, Ca shows minima at $145 \mathrm{~cm}$ depth and between 115 and $95 \mathrm{~cm}$ depth (Fig. 6b). The Ca distribution derived from
XRF scans is significantly correlated with the $\mathrm{CaCO}_{3}$ content for both profiles (KG-5753 $R^{2}=0.55$ and KG-5756/57 $R^{2}=0.84$ ). For this correlation, XRF Ca clr values are averaged in $10 \mathrm{~mm}$ steps to account for the lower resolution of $\mathrm{CaCO}_{3}$ analyses.

\subsection{Radiocarbon dating}

Radiocarbon dating of different materials shows high variabilities (Table 1).

Only sample KG-5757-77-C reveals an expected age range of 28 930-27 $830 \mathrm{cal} \mathrm{BP}$. This piece of charcoal derives from the upper part of the tundra gley. Terrestrial gastropods from 
the upper part of the loess section KG-5753 reveal ${ }^{14} \mathrm{C}$ ages between approximately 11 and $15 \mathrm{kacal} \mathrm{BP}$. In some cases, however, the results show age inversions. Humic acids as well as rhizoconcretions (CRC and $\mathrm{HC}$ ) reveal a Holocene formation. Sample KG-5753-33-C was most likely a recent root, which explains the postmodern age, i.e. younger than $1950 \mathrm{CE}$.

\subsection{Stable isotopes of carbonate concretions}

In KG-5753, 43 samples contain sufficient CRC for isotope analyses. The $\delta^{18} \mathrm{O}_{\mathrm{CRC}}$ values range from $-13.8 \%$ to $-7.2 \%$. The $\delta^{13} \mathrm{C}_{\mathrm{CRC}}$ range is exceptionally high with values ranging from $-30.9 \%$ to $-6.7 \%$ (Fig. 7a). At about $45 \mathrm{~cm}$ depth, an increase is detectable for the $\delta^{18} \mathrm{O}_{\mathrm{CRC}}$ and $\delta^{13} \mathrm{C}_{\mathrm{CRC}}$ records of both profiles. Furthermore, $\delta^{18} \mathrm{O}_{\mathrm{CRC}}$ and $\delta^{13} \mathrm{C}_{\mathrm{CRC}}$ are significantly correlated $\left(R^{2}=0.70\right)$. HC were found in 70 samples in KG-5753. The $\delta^{18} \mathrm{O}_{\mathrm{HC}}$ values range from $-11.7 \%$ o to $-4.8 \%$ and $\delta^{13} \mathrm{C}_{\mathrm{HC}}$ from $-8.9 \%$ o to $-1.9 \%$.

In KG-5756/57, isotope analyses of CRC were limited to 73 samples with sufficient amount. The $\delta^{18} \mathrm{O}_{\mathrm{CRC}}$ values range from $-14.2 \%$ to $-5.7 \%$. The lowest $\delta^{13} \mathrm{C}_{\mathrm{CRC}}$ value is $-29.9 \%$ and the highest $-3.9 \%$ (Fig. $7 \mathrm{~b}$ ). $\delta^{18} \mathrm{O}_{\mathrm{CRC}}$ and $\delta^{13} \mathrm{C}_{\mathrm{CRC}}$ records are significantly correlated $\left(R^{2}=0.68\right)$. $\mathrm{HC}$ were found in 114 samples in KG-5756/57. The $\delta^{18} \mathrm{O}_{\mathrm{HC}}$ values range from $-6.8 \%$ to $-4.2 \%$ and the $\delta^{13} \mathrm{C}_{\mathrm{HC}}$ values from $-8.0 \%$ to $-1.2 \%$ (Fig. $7 \mathrm{~b}$ ). $\delta^{18} \mathrm{O}_{\mathrm{HC}}$ and $\delta^{13} \mathrm{C}_{\mathrm{HC}}$ records are significantly correlated $\left(R^{2}=0.89\right)$.

\section{Discussion}

\subsection{Age determination and stratigraphy}

Previous ${ }^{14} \mathrm{C}$ measurements of bones and teeth obtained from archaeological layers revealed ages between 23.7 and 22.1 ka cal BP (Haesaerts et al., 2016; Händel et al., 2021). Optically stimulated luminescence (OSL) ages provide additional age control for over- and underlying strata (Händel et al., 2021). These samples stem from different profiles but from the same stratigraphic positions (Figs. 1 and 2) and are listed with published radiocarbon measurements from the archaeological horizons in Table 2.

In our study, we also tested radiocarbon age determinations on various materials regarding reliability and consistency. Only two samples, namely a piece of charcoal (KG5757-77-C) and a terrestrial snail (KG-5753-33-S), revealed results in the expected age range to be considered reliable (Table 1). However, the ${ }^{14} \mathrm{C}$ age of the analysed gastropod should be considered with caution since a second terrestrial snail (KG-5753-59-S) with a younger age was found about $20 \mathrm{~cm}$ deeper (Table 1). This uncertainty could be related to the small quantity of the snail samples $(<1.7 \mathrm{mg})$ or to possible relocation caused by bioturbation. In general, the ingestion of dead carbon can also influence radiocarbon ages of terrestrial snails. This effect was observed in $22 \%$ of modern snails dated in the course of a comprehensive study in North America (Pigati et al., 2010). However, this effect cannot explain the age of KG-5753-59-S, which appears too young and can thus not serve as an explanation for this case. We rather assume that this particular sample possibly contained carbonate contamination of more recent age; i.e. the sample shows an open-system behaviour. Ages of gastropods were compared with charcoal ages in a study of the Dunaszekcsô loess record (Újvári et al., 2016a). In that study, 7 out of 11 mollusc shells revealed a similar age to charcoal samples from the same stratigraphic levels, suggesting a predominantly closed-system behaviour for radiocarbon of loess snails, while at least one of these samples also clearly showed an open-system behaviour, similarly to our study.

At least the formation of CRC has frequently been described as synsedimentary (Becze-Deák et al., 1997; Wang and Greenberg, 2007; Barta, 2011, 2014; Koeniger et al., 2014). Radiocarbon ages of HC and CRC in our study do not support this assumption. Generally, the formation of CRC is linked to $\mathrm{CaCO}_{3}$ in the soil matrix, which is dissolved by $\mathrm{H}^{+}-\mathrm{HCO}_{3}^{-}$exchange. $\mathrm{Ca}^{2+}$ then becomes available for the plant and is subsequently absorbed by roots and accumulates in the vacuole where it precipitates as $\mathrm{CaCO}_{3}$. While the cells calcify, the outer part of the cells, namely the parenchyma cells of the roots, mineralise during plasmolysis (BeczeDeák et al., 1997; Barta, 2011). For the formation of HC, two main hypotheses exist (Becze-Deák et al., 1997; Barta, 2011). The origin of the HCs either can be attributed to the evaporation of Ca-rich solutions from the soil matrix or may be due to carbonate precipitation from the soil solution into the soil matrix or along the pores (Barta, 2011). The other hypothesis is related to the metabolism of the roots. The release of $\mathrm{CO}_{2}$ leads to the crystallisation of dissolved calcium from the soil solution, resulting in the formation of micrite crystals. Cemented together, they enclose the root remnants or rather the pores formed by the roots within the soil matrix (Becze-Deák et al., 1997; Barta, 2011).

To conclude, the ${ }^{14} \mathrm{C}$ results of secondary carbonate concretions further corroborate previous findings that they cannot be used for dating purposes of loess deposits of Late Pleistocene age (Gocke et al., 2011; Újvári et al., 2014). With regard to their young ages, they cannot be linked to soil processes during loess build-up. In our study, humic acids also provided Holocene ages and thus were too young to be used for age inferences of the loess sections. This is in contradiction to previous studies in which humic acid fractions were considered reliable (Runge et al., 1973; Wang et al., 2014).

In summary, the most reliable age determination from the loess section in our study derives from a singular sample with charcoal particles. Such particles, however, are very scarce at Kammern-Grubgraben. As an alternative for future dating approaches, the more abundant terrestrial snails could provide an option for layers where neither charcoal nor hard tissue vertebrate remains are available. However, more studies 

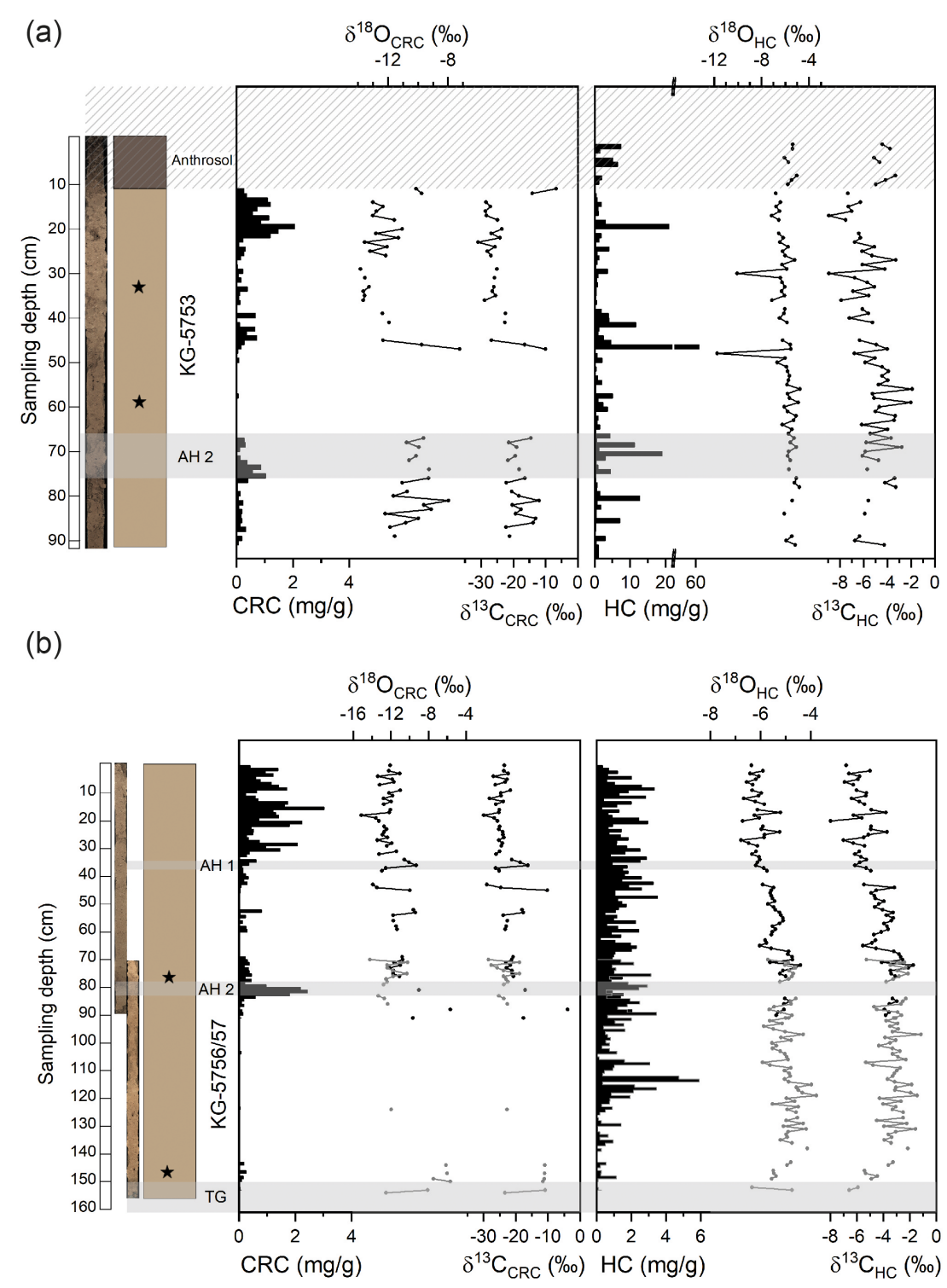

Figure 7. Stable isotope data of secondary carbonates (CRC and HC) and their concentration (mg g ${ }^{-1}$ ) along the profile in (a) KG-5753 and (b) KG-5756/57. The hatched area in (a) represents the base of the sampled Anthrosol; shaded areas represent the archaeological horizons (AH 1 and $\mathrm{AH}$ 2) and the tundra gley (TG). Black stars symbolise the positions of radiocarbon samples. Missing values are due to the absence of secondary carbonates at their respective positions and are indicated by gaps. Note the axis break and scale change in (a) for the concentration of $\mathrm{HC}$.

are needed with larger amounts of gastropod material. Such a larger amount of snail carbonate would also allow a controlled mild acid pretreatment to remove shell contaminations prior to dating as proposed by Újvári et al. (2016a), which was not reliably carried out in our study.

\subsection{Critical evaluation of secondary pedogenic carbonate isotopes}

The isotopic composition of secondary pedogenic carbonates has been frequently studied (e.g. Cerling, 1984; Dworkin et al., 2005; Gocke et al., 2011; Koeniger et al., 2014). The variable concentration of microscale secondary carbonates in loess sequences is thought to be a sensitive indicator of environmental changes, such as alternating dust accumulation or changes in moisture regime (Barta, 2014; Koeniger et al., 2014). The formation of secondary carbonates is mostly accompanied by relocation (vertical, horizontal) of primary carbonates in the sediment (Barta, 2011, 2014; Koeniger et al., 2014). Vertical relocation is linked either to infiltration of meteoric water, which leads to leaching and thus to dissolution and re-precipitation of carbonates, or to poreand groundwater rising through evaporation, which results in upward dislocation (Monger, 2002; Barta, 2014). In situ- 
Table 2. OSL and radiocarbon ages from Händel et al. (2021). Note that radiocarbon dates were re-calibrated with IntCal20 (Reimer et al., 2020). For OSL dating, quartz in the fraction of 63-90 $\mu \mathrm{m}$ was used.

\begin{tabular}{|c|c|c|c|c|c|c|}
\hline Lab no. & $\begin{array}{l}\text { Type } \\
\text { of } \\
\text { sample }\end{array}$ & $\begin{array}{l}\text { Material and } \\
\text { species }\end{array}$ & $\begin{array}{l}\text { Approximate depth } \\
(\mathrm{cm}) \text { and } \\
\text { archaeological layer }\end{array}$ & $\begin{array}{r}\text { Age (BP) } \\
\pm 1 \sigma\end{array}$ & $\begin{array}{r}\text { Calibrated age range } \\
\text { (cal BP) and } \\
\text { probabilities }(2 \sigma)\end{array}$ & $\begin{array}{r}\text { OSL age } \\
(\mathrm{ka}) \\
\pm 1 \sigma\end{array}$ \\
\hline \multirow[t]{2}{*}{ MAMS-32966 } & \multirow[t]{2}{*}{${ }^{14} \mathrm{C}$} & \multirow[t]{2}{*}{ reindeer tooth } & \multirow[t]{2}{*}{$35(\mathrm{AH} 1)$} & \multirow[t]{2}{*}{$18590 \pm 60$} & $22750-22710(0.012)$ & \\
\hline & & & & & $22690-22340(0.988)$ & \\
\hline MAMS-26430 & ${ }^{14} \mathrm{C}$ & horse/reindeer bone & $\begin{array}{l}81-76 \text { (AH } 102, \\
\text { corr. to AH 2) }\end{array}$ & $18300 \pm 70$ & 22 400-22 090 (1.000) & \\
\hline \multirow[t]{2}{*}{ MAMS-30165 } & \multirow[t]{2}{*}{${ }^{14} \mathrm{C}$} & \multirow[t]{2}{*}{ horse/reindeer bone } & \multirow[t]{2}{*}{ 81-76 (AH 2) } & \multirow[t]{2}{*}{$19250 \pm 70$} & $23690-23600(0.063)$ & \\
\hline & & & & & $23360-22970(0.937)$ & \\
\hline MAMS-40115 & $r^{14} \mathrm{C}$ & horse/reindeer bone & $81-76(\mathrm{AH} 2)$ & $18860 \pm 60$ & $22970-22560(1.000)$ & \\
\hline \multirow[t]{2}{*}{ MAMS-40116 } & \multirow[t]{2}{*}{${ }^{14} \mathrm{C}$} & \multirow[t]{2}{*}{ horse/reindeer bone } & \multirow[t]{2}{*}{$81-76$ (AH 2) } & \multirow[t]{2}{*}{$19230 \pm 60$} & $23670-23630(0.021)$ & \\
\hline & & & & & $23330-22960(0.979)$ & \\
\hline KG-1476 & OSL & quartz & $18-27$ & & & $26.8 \pm 2.1$ \\
\hline KG-1477 & OSL & quartz & $18-27$ & & & $19.8 \pm 1.6$ \\
\hline KG-1479 & OSL & quartz & $48-70$ & & & $19.5 \pm 1.6$ \\
\hline KG-1480 & OSL & quartz & $48-70$ & & & $21.6 \pm 1.8$ \\
\hline KG-931 & OSL & quartz & $93-103$ & & & $26.2 \pm 2.1$ \\
\hline KG-932 & OSL & quartz & $93-103$ & & & $25.3 \pm 1.9$ \\
\hline KG-1482 & OSL & quartz & $93-103$ & & & $25.6 \pm 2.0$ \\
\hline KG-1483 & OSL & quartz & $93-103$ & & & $25.5 \pm 2.0$ \\
\hline
\end{tabular}

formed secondary carbonates are associated with chemical weathering of the surrounding substrate (Pécsi, 1990; Monger, 2002; Barta, 2014). The precipitation of carbonates is associated with solution of weathered $\mathrm{Ca}^{2+}$, which results from root and microbial respiration (Becze-Deák et al., 1997; Monger, 2002; Barta, 2014).

In our study, the distribution of CRC and $\mathrm{HC}$ in the profiles is not congruent. CRC accumulated at the top of the loess profile and in AH 2 but are largely absent in the Anthrosol below AH 2 and around $65 \mathrm{~cm}$ sampling depths. In contrast, $\mathrm{HC}$ are more evenly distributed and also occur in the Anthrosol (Fig. 7). This may indicate different time periods of formation, as also suggested by the radiocarbon ages of $\mathrm{HC}$ that are ca. 3400 years older compared to CRC at $11 \mathrm{~cm}$ depth of $\mathrm{KG} \mathrm{5757,} \mathrm{corresponding} \mathrm{to} \mathrm{AH} 2$ (Table 1). Both ages are far too young for $\mathrm{AH} 2$, which was deposited between 23.7 and $22.1 \mathrm{ka}$ cal BP (Händel et al., 2021). Interestingly, the $\delta^{13} \mathrm{C}$ values of CRC and $\mathrm{HC}$ also differ largely (average $-22 \%$ and $-4 \%$, respectively). Similar differences are also reported by Koeniger et al. (2014) and Luo et al. (2020). The lower $\delta^{13} \mathrm{C}$ values of CRC suggest a formation from respiratory $\mathrm{CO}_{2}$, which typically has $\delta^{13} \mathrm{C}$ values close to leaf biomass (Bowling et al., 2008). However, various admixtures of atmospheric $\mathrm{CO}_{2}$ can increase $\delta^{13} \mathrm{C}$ values substantially (Cerling, 1984), which is probably the reason for the much more ${ }^{13} \mathrm{C}$-enriched values of $\mathrm{HC}$. Thus, it seems that two different sources, respiratory $\mathrm{CO}_{2}$ and atmospheric $\mathrm{CO}_{2}$, predominated during the Holocene formation of $\mathrm{CRC}$ and $\mathrm{HC}$, respectively.

In contrast, Koeniger et al. (2014) suggest that stable isotope variability is linked to palaeoclimatic variations and assume that the formation of CRC and $\mathrm{HC}$ is associated with the time of dust accumulation. They further propose that stable isotope records of secondary carbonates in loess records are reliable palaeoenvironmental proxies for moisture and soil formation processes (Koeniger et al., 2014). Our results, however, show that this is not necessarily the case as the rhizoconcretions (CRC and $\mathrm{HC}$ ) were considerably younger than the surrounding loess. In several other studies, rhizoconcretions in loess also reveal a Holocene formation and thus confirm a post-sedimentary origin (e.g. Pustovoytov and Terhorst, 2004; Gocke et al., 2011; Újvári et al., 2014). Such overprinting of loess profiles with Holocene material or invading of post-sedimentary deep roots may bias the results of loess-based palaeoenvironmental studies (Gocke, 2011). Under laboratory and field conditions, the importance of vegeta- 
tion for the formation and re-crystallisation of pedogenic carbonates was shown by Gocke (2011). Roots and microorganisms had a direct influence on these processes, while climatic factors exerted indirect influence. A correct interpretation of the isotopic composition of secondary carbonates thus also requires considering the evolution of carbonates in the soil (Koeniger et al., 2014), i.e. an exchange of carbon from primary loess carbonates with carbon from the air $\left(\mathrm{CO}_{2}\right)$ during the formation of rhizoliths by respiration of roots and microorganisms (Gocke et al., 2011).

Due to their Holocene formation, the isotope results of secondary carbonates can also not be used for tracing glacial palaeoenvironmental conditions. Therefore, our results have implications for other stable isotope studies on rhizoconcretions, and we recommend testing post-sedimentary formation via radiocarbon dating prior to using them for palaeoenvironmental reconstructions.

\subsection{Environmental implications from other geochemical proxies and grain size}

The $\delta^{13} \mathrm{C}_{\text {org }}$ variations in both profiles show a range typical of $\mathrm{C}_{3}$ vegetation (O'Leary 1981; Rounick and Winterbourn, 1986; Hatté et al., 1998), which can be considered prevalent during the Late Pleistocene in this area (Arppe et al., 2011; Schatz et al., 2011; Kovács et al., 2012). During the period of human occupation (at the time of $\mathrm{AH} 1$ and $\mathrm{AH} 2$; ca. $23 \mathrm{ka} \mathrm{cal} \mathrm{BP}$ ), the presence of a steppe-like open grassland can be assumed (Stojakowits et al., 2021). However, clusters of woody vegetation (Pinus cembra and Juniperus sp.) were also present as inferred from pollen data of the archaeological site (Montet-White et al., 1990; Haesaerts and Damblon, 2016).

This type of ecosystem can also be reconstructed based on the distribution of gastropods. In our study, the distribution of gastropods shows no differences between horizons. Almost exclusively Vallonia costata occurs except for one single sample of Pupilla sp., which derives from the underlying tundra gley of profile KG-5756/57. Frank and Rabeder $(1996,1997)$ found 18 terrestrial gastropod taxa in the Kammern-Grubgraben profile, but their stratigraphic context is unclear. The Kammern-Grubgraben mollusc fauna indicates a herb-rich meadow steppe, partly with shrubs and isolated groups of trees. Among others, Vallonia costata and $V$. pulchella are especially common in milder cold-period sections (Ložek, 1964, 1982; Mania, 1973; Fúköh, 1993; Krolopp and Sümegi, 1995; Frank, 2006). In contrast, Vallonia tenuilabris, the indicator species of colder periods that is widespread in central Europe, has so far been absent from Kammern-Grubgraben. With Columella columella, however, at least one element of a cold tundra was recorded.

Although $\delta^{13} \mathrm{C}_{\text {org }}$ values range between $-24 \%$ and $-28 \%$ in both sections, their variability does not show a clear palaeoclimatic trend. The slight increase at the base of profile KG-5756/57 may indicate a shift from drier condi- tions for older sediments to more humid conditions upwards considering the fact that water loss through evapotranspiration is limited by stomatal constriction of the plants. This physiological reaction is accompanied by a reduced carbon isotope fractionation resulting in higher $\delta^{13} \mathrm{C}$ values (Hatté et al., 1998). Water availability may be inferred based on the $\delta^{13} \mathrm{C}$ values of organic matter. It seems, however, that the results are not in accordance with the TOC and $\mathrm{CaCO}_{3}$ contents. Apart from the upper part of profile KG-5753, which is influenced by the overlying modern Anthrosol, explaining its high TOC content $(0-13 \mathrm{~cm}$ depth, Fig. 5a), values vary between $0.2 \%$ and $0.4 \%$ (min value $0.1 \%$ and max value $0.9 \%$ in KG-5753; Fig. 5) for both profiles. Typical glacial loess deposits in northwestern Europe show organic carbon contents of less than $0.1 \%$ (Antoine et al., 2013; Mayr et al., 2017b). However, increased TOC contents, as recorded at the base of KG-5756/57, might be a result of accumulation or preservation of organic carbon due to warmer and/or wetter climate conditions (Zech et al., 2013; Mayr et al., 2017b), but any environmental inferences from our TOC record are hampered by unknown dust accumulation rates.

Implications about moisture can also be derived from the calcium contents, since the moisture regime of the soil influences the $\mathrm{CaCO}_{3}$ content and the Ca distribution (Monger, 2002; Barta, 2014). Under more humid conditions, $\mathrm{Ca}$ is sensitive to leaching (Buggle et al., 2011; Barta, 2014; Profe et al., 2018b), which may explain the decreasing trend of $\mathrm{Ca}$ and $\mathrm{CaCO}_{3}$ towards the bottom in both profiles (Fig. 6). XRF scanning from Chinese LPSs revealed that $\mathrm{Ca}$ and $\mathrm{Si}$ decrease in palaeosol layers relative to the surrounding loess sediments (Sun et al., 2016). This is also evident from an LPS from Süttô, Hungary, where Ca / Ti ratios derived from high-resolution XRF scanning of discrete samples are used as a proxy for weathering intensity, and, consequently, low $\mathrm{Ca} / \mathrm{Ti}$ values are explained by decalcification (Profe et al., 2018b). Thus, our observations could suggest a climatic shift from more humid-warmer conditions during the formation of the older sediments towards drier-colder conditions during the main occupation period, which was also reported by Haesaerts and Damblon (2016). Whether such climatic changes are related to the postulated shift of storm tracks in the Alpine area during the LGM (Luetscher et al., 2015) remains to be investigated in more detail in future studies using longer LPSs. Additionally, dust sources may have changed, as glaciers progressively advanced into the Alpine foreland between 30 and $25 \mathrm{ka}$ cal BP and retreated again before $22 \mathrm{ka}$ cal BP (Stojakowits et al., 2021). In contrast, geochemical provenancing and $\mathrm{U}-\mathrm{Pb}$ isotope dating of detrital zircons in loess from the Krems area suggest a predominant source from nearby Bohemian Massif sources $(<10 \mathrm{~km})$. This implies an initial fluvial transport and a subsequent aeolian re-deposition in the study area rather than changes in palaeowind directions (Újvári and Klötzli, 2015). However, such provenance data would have to be extended to also infer the temporal changes in dust sources. 
$\mathrm{Ti}$ is frequently a component of weathering-resistant minerals such as titanium oxides and ilmenite (Profe et al., 2018b; Mayr et al., 2019). The elements Fe and Ti behave very similarly and show a negative covariance with $\mathrm{Ca}$ in our records (Fig. 6a, b). Ti and Fe are likely considered to be of detrital origin and mainly influenced by varying concentrations of carbonates. In contrast, $\mathrm{K}$ and $\mathrm{Si}$ also show negative correlations with $\mathrm{Ca}$ below $\mathrm{AH} 2$ but do not exhibit a decreasing trend from bottom to top as Fe and Ti do (Fig. 6a, b). $\mathrm{K}$ is frequently bound to mica, feldspars, and clay minerals (Mayr et al., 2019). The rather evenly distributed clay contents in the profiles (Fig. 4a, b) may explain the small variations in the $\mathrm{K}$ record. The slight increase in $\mathrm{K}$ below AH 2 (Fig. 6b), however, cannot be explained with clay content alone but rather by increased sand input (Profe et al., 2018b). K-feldspars are a common constituent of the sandsized fraction in loess sequences of Lower Austria (Thiel et al., 2011b), possibly explaining the increase in that stratigraphic level. In the long $>100 \mathrm{kyr}$ loess record from Süttő, $\mathrm{Si} / \mathrm{K}$ and $\mathrm{Ca} / \mathrm{Ti}$ ratios are correlated with grain size and carbonate content, respectively (Profe et al., 2018b). In our records, these element ratios do not provide additional information to the clr-transformed element records (Fig. S1 in the Supplement), and their variability in the short time period covered by our LGM record is expected to be small (Profe et al., 2018b).

The climate conditions at the Marine Isotope Stage (MIS) 3-2 transition are characterised by climatic deterioration. However, two short interstadials (GI-4 and GI-3) were recorded and placed at 28.8 and $27.7 \mathrm{ka}$ (Rasmussen et al., 2014). The lower part of KG-5756/57 corresponds to the late phase of MIS 3 or the MIS 3-MIS 2 transition (Stojakowits et al., 2021), as inferred from the radiocarbon age of a charcoal fragment (ca. 28.9-27.8 ka cal BP, Table 1) deriving from the basal tundra gley. Gleyic features from this period are also reported from other LPSs in the Alpine realm (Buch and Zöller, 1990; Moine et al., 2017; Mayr et al., 2017b) and related to a warming event, possibly related to GI-4 with milder climate conditions (Mayr et al., 2017b; Stojakowits et al., 2021). This timeframe is also supported by luminescence data for the loess unit between tundra gley and the main archaeological horizon AH 2 (KG-931, KG-932 and KG-1482, KG-1483; Fig. 2a, c; Table 2). A connection of the deposition of this sediment to Greenland Stadial 3 (GS-3) has been proposed by Händel et al. (2021).

For the loess build-up, palaeowind intensity plays an important role (Buggle et al., 2008; Ludwig et al., 2021). In general, grain-size distribution in loess is mainly linked to wind intensity and thus may provide information about the distance as well as the main source of the sediment (Gavrilov et al., 2018) in combination with single-grain geochemical provenancing (Újvári and Klötzli, 2015). Colder periods are associated with high wind intensity, resulting in an accumulation of coarser grains, whereas the distribution of finer grains is related to weaker or constant winds in warmer peri- ods (Novothny et al., 2011). However, this simplified relation is weakened if the distance to the source changes in time and valid only if several other factors like topography play a minor role (Újvari et al., 2016b). Grain-size parameters such as the $U$ ratio combined with clay content (Vanderberghe et al., 1997; Vanderberghe, 2013) or the grain-size index (Rousseau et al., 2002) are often used to reconstruct wind dynamics. In KG-5756/57, the clay content is slightly higher in the basal tundra gley, while the $U$ ratio and the grain-size index show lower values. This is in accordance with previous findings, e.g. in the Nussloch section in Germany, where higher grainsize indices were found in coarser grain-sized loess while the lowest values corresponded to tundra-gley units (Rousseau et al., 2002). Higher grain-size indices were further correlated with higher $\delta^{13} \mathrm{C}$ values, which was explained by stronger wind dynamics accompanied by drier environmental conditions and decreased vegetation cover. This pattern, however, is not clearly evident in our study, where a significant trend is absent in the $\delta^{13} \mathrm{C}_{\text {org }}$ record and the dominant grain-size fraction is cSi (Fig. 4). This is also reflected by the geochemical composition; silicon ( $\mathrm{Si}$ ) in aeolian sediments is preferentially linked to grain-size fractions like coarse silt and sand (Muhs and Bettis, 2000; Buggle et al., 2008), which explains the constantly high amounts of $\mathrm{Si}$ in both analysed profiles (Fig. 6). However, the overall percentage of coarse sand is rather low, pointing to reduced wind intensities and continuous dust accumulation. According to Novothny et al. (2011), a coarse sand content of $<0.5 \%$ refers to lower palaeowind intensities, indicating rather low wind energy during loess deposition, which is documented for both analysed profiles (KG-5753 and KG-5756/57). It is noticeable, though, that the sand fraction is more prevalent shortly above and below the main archaeological layer (AH 2) in both profiles (Fig. 4). This could point to an increase in wind intensity during these specific periods. Physical weathering of the stone slabs, introduced by hunter-gatherer occupants into the archaeological layer from nearby rock sources, can largely be excluded as a source for the sand fraction due to its short exposure to the atmosphere. Examinations of the profiles in the field, however, also revealed the presence of undulating sandy bands of a few centimetres' thickness. As the site is located between two erosion channels with gradients to the north, south, and east, this is more likely a result of slope processes (e.g. solifluction or surficial creep) and thus attributable to the overall topography rather than to aeolian processes.

To summarise, based on the proxies we evaluated, we could not find indications for a period of ameliorated climate during the AH 2 phase, as previously postulated by Haesaerts and Damblon (2016). Our data suggest rather constant environmental conditions before, during, and after the formation of AH 2. Only the tundra gley exposed at the base of KG$5756 / 57$ points at more favourable conditions. 


\section{Conclusions}

We applied a multi-proxy approach to two profiles exposed by recent excavations at the Upper Palaeolithic site of Kammern-Grubgraben, including analyses of grain size, organic geochemistry (TOC, TN, C / N,$\delta^{13} \mathrm{C}_{\mathrm{org}}$ ), inorganic geochemistry (XRF-based elemental counts, $\mathrm{CaCO}_{3}$ ), and stable isotope analyses $\left(\delta^{13} \mathrm{C}, \delta^{18} \mathrm{O}\right)$ of secondary carbonates (HC, CRC). In addition, we radiocarbon-dated different material from the same stratigraphic layers and compared these to previously obtained ages (AH 2). Our analyses showed that secondary carbonates and humic acids were formed during the Holocene as manifested by their radiocarbon ages. Therefore, loess profiles in the excavation area are overprinted by Holocene deep-rooting vegetation. In our study, we were able to extract, for the first time, a sufficiently large charcoal sample for obtaining a radiocarbon age of 28930 $27830 \mathrm{cal}$ BP from the tundra gley underneath AH 2, which could be related to interstadial conditions during GI-4 or GI3. Terrestrial gastropods provided another source for radiocarbon ages, albeit the low sample amounts probably affected dating quality.

XRF core scanning provided high-resolution element distributions, which were calibrated using centred log-ratio transformation. Ca represents the most pronounced element record and is in agreement with the independently analysed $\mathrm{CaCO}_{3}$ record. To our knowledge, we provide the first continuous XRF-scanning record on a European loess sequence and demonstrate that this technique provides reliable results for the most abundant elements.

In order to provide more detailed information about palaeoenvironmental and climatic conditions, extractions of longer, undisturbed LPSs are essential for future studies, as the studied sections were rather short and close to the modern surface. In addition, material suitable for radiocarbon age determination is scarce outside of archaeological horizons, causing difficulties for obtaining chronological control. Such prerequisites make it worthwhile to examine LPSs from sites as close by as possible to the archaeological site to obtain more datable material. XRF scanning could be extremely useful to synchronise these LPSs with the archaeological trench sections.

Data availability. Original data will be made available via the database PANGAEA after publication.

Supplement. The supplement related to this article is available online at: https://doi.org/10.5194/egqsj-71-23-2022-supplement.

Author contributions. CM designed the sedimentological investigations with contributions of TE, AM, KP, US, and MH. Fieldwork was carried out by CM, TE, US, and MH. CS and LR carried out most of the laboratory work with contributions of CM. SM identified terrestrial gastropods. LR wrote the original draft with contributions of CM, MH, BZ, and CS. All co-authors reviewed and approved the manuscript.

Competing interests. The contact author has declared that neither they nor their co-authors have any competing interests.

Disclaimer. Publisher's note: Copernicus Publications remains neutral with regard to jurisdictional claims in published maps and institutional affiliations.

Acknowledgements. We acknowledge the German Research Foundation (DFG) for financial support; Rafael Stiens for technical assistance with grain-size analyses and evaluation; Christian Ohlendorf for help with XRF scanning; Ute Schmidt for assistance with elemental analyses; and Nadja Schlieder, Roswitha Höfner-Stich, and Philipp Bartmann for assistance in the isotope laboratory. We thank the two anonymous reviewers for their comments to improve a previous version of the manuscript and the editor and editorial team for their thorough editorial handling.

Financial support. This research has been supported by the Deutsche Forschungsgemeinschaft (grant no. MA 4235/12-1, project no. 424736737).

Review statement. This paper was edited by Christopher Lüthgens and reviewed by two anonymous referees.

\section{References}

Adovasio, J. M., Soffer, O., and Klíma, B.: Upper Palaeolithic fibre technology: interlaced woven finds from Pavlov I, Czech Republic, c. 26,000 years ago, Antiquity, 70, 526-534, https://doi.org/10.1017/S0003598X0008368X, 1996.

Aitchison, J.: The statistical analysis of compositional data, J. Roy. Stat. Soc. B, 44, 139-177, 1982.

Antoine, P., Rousseau, D.-D., Moine, O., Kunesch, S., Hatté, C., Lang, A., Tissoux, H., and Zöller, L.: Rapid and cyclic aeolian deposition during the Last Glacial in European loess: a highresolution record from Nussloch, Germany, Quaternary Sci. Rev., 28, 2955-2973, 2009.

Antoine, P., Rousseau, D.-D., Degeai, J.-P., Moine, O., Lagroix, F., Kreutzer, S., Fuchs, M., Hatté, C., Gauthier, C., Svoboda, J., and Lisá, L: High-resolution record of the environment response to climatic variations during the Last Interglacial-Glacial cycle in Central Europe: the loess paleosol sequence of Dolní Vĕstonice (Czech Republic), Quaternary Sci. Rev., 67, 17-38, 2013.

Arppe, L., Aaris-Sørensen, K., Daugnora, L., Lõugas, L., Wojtal, P., and Zupiòš, I.: The palaeoenvironmental $\delta^{13} \mathrm{C}$ record in European woolly mammoth tooth enamel, Quatern. Int., 245, 2885290, 2011. 
Barta, G.: Secondary carbonates in loess-paleosoil sequences: a general review, Cent. Eur. J. Geosci., 3, 129-146, 2011.

Barta, G.: Paleoenvironmental reconstruction based on the morphology and distribution of secondary carbonates of the loesspaleosol sequence at Süttő, Hungary, Quatern. Int., 319, 64-75, 2014.

Becze-Deák, J., Langohr, R., and Verrecchia, E. P.: Small scale secondary $\mathrm{CaCO}_{3}$ accumulations in selected sections of the European loess belt. Morphological forms and potential for paleoenvironmental reconstructions, Geoderma, 76, 221-252., 1997.

Blott, S. J. and Pye, K: GRADISTAT: A grain size distribution and statistic package for the analysis of unconsolidated sediments, Earth Surf. Proc. Land., 26, 1237-1248, 2001.

Bowling, D. R., Pataki, D. E., and Randerson, J. T.: Carbon isotopes in terrestrial ecosystem pools and $\mathrm{CO}_{2}$ fluxes, New Phytol., 178, 24-40, https://doi.org/10.1111/j.1469-8137.2007.02342.x, 2008.

Brand, W. A., Coplen, T. B., Vogl, J., Rosner, M., and Prohaska, $\mathrm{T}$ : Assessment of international reference materials for isotoperatio analysis (IUPAC Technical Report), Pure Appl. Chem., 86, 425-467, 2014.

Brandtner, F.: Zur geostratigraphischen und kulturellen Zuordnung der Paläolithstation Grubgraben bei Kammern, NÖ, in: Paleolithic in the Middle Danube Region, edited by: Svoboda, J., Festschrift for B. Klíma, Dolní Věstonice Studies 4, Brno, 121146, 1996.

Bronger, A.: Löß-Paläoboden-Sequenzen Zentralasiens als Indikatoren einer globalen Kimageschichte des Quartärs?, E\&G Quaternary Sci. J., 49, 35-54, https://doi.org/10.3285/eg.49.1.03, 1999.

Bronger, A.: Correlation of loess-paleosol sequences in East and Central Asia with SE Central Europe: towards a continental Quaternary pedostratigraphy and paleoclimatic history, Quatern. Int., 106-107, 11-31, 2003.

Buch, M. W. and Zöller, L.: Gliederung und ThermolumineszenzChronologie der Würmlösse im Raum Regensburg, E\&G Quaternary Sci. J., 40, 63-84, https://doi.org/10.3285/eg.40.1.05, 1990.

Buggle, B., Glaser, B., Zöller, L., Hambach, U., Marković, S., Glaser, I., and Gerasimenko, N.: Geochemical characterization and origin of Southeastern and Eastern European loesses (Serbia, Romania, Ukraine), Quaternary Sci. Rev., 27, 1058-1075, 2008.

Buggle, B., Hambach, U., Glaser, B., Gerasimenko, N., Marković, S., Glaser, I., and Zöller, L.: Stratigraphy, and spatial and temporal paleoclimatic trends in Southeastern/Eastern European loesspaleosol sequences, Quatern. Int., 196, 86-106, 2009.

Buggle, B., Glaser, B., Hambach, U., Gerasimenko, N., and Marković, S.: An evaluation of geochemical weathering indices in loess-paleosol studies, Quatern. Int., 240, 12-21, 2011.

Cerling, T. E.: The stable isotopic composition of modern soil carbonate and its relationship to climate, Earth Planet. Sc. Lett., 71, 229-240, 1984

Clark, P. U., Dyke, A. S., Shakun, J. D., Carlson, A. E., Clark, J., Wohlfarth, B., Mitrovica, J. X., Hostetler, S. W., and McCabe, A. M.: The last glacial maximum, Science 325, 710-714, https://doi.org/10.1126/science.1172873, 2009.

d-maps: Landkarte Niederösterreich (Österreich), d-maps, https: //d-maps.com/carte.php?num_car=33842\&lang=de, last access: 28 April 2021.
Dworkin, S. I., Nordt, L., and Atchley, S.: Determining terrestrial paleotemperatures using the oxygen isotopic composition of pedogenic carbonate, Earth Planet. Sc. Lett., 237, 56-68, 2005.

Fewlass, H., Talamo, S., Kromer, B., Bard, E., Tuna, T., Fagault, Y., Sponheimer, M., Ryder, C., Hublin, J.-J., Perri, A., Sázelová, S., and Svoboda, J.: Direct radiocarbon dates of mid Upper Palaeolithic human remains from Dolní Věstonice II and Pavlov I, Czech Republic, J. Archaeol. Sci.: Reports, 27, 102000, https://doi.org/10.1016/j.jasrep.2019.102000, 2019.

Fink, J.: Die fossilen Böden im österreichischen Löss, Quartär, 6, 85-108, 1954.

Fink, J.: Studien zur absoluten und relativen Chronologie der fossilen Böden in Österreich. II. Wetzleinsdorf und Stillfried, Archaeologia Austriaca, 31, 1-18, 1962.

Fink, J.: Exkursion durch den österreichischen Teil des Alpenvorlandes und den Donauraum zwischen Krems und Wiener Pforte, Mitteilungen der Quartärkommission der Österreichischen Akademie der Wissenschaften, Vienna, 1, 1-113, 19761978.

Fitzsimmons, K. E., Marković, S. B., and Hambach, U.: Pleistocene environmental dynamics recorded in the loess of the middle and lower Danube basin, Quaternary Sci. Rev., 41, 104-118, 2012.

Frank, C.: Plio-pleistozäne und holozäne Mollusken Österreichs, Mitteilungen der Prähistorischen Kommission, 62, 860 pp., ISBN 978-3-7001-3674-3, 2006.

Frank, C. and Rabeder, G.: Neue malakologische Befunde aus dem jüngstpleistozänen Lößprofil vom Grubgraben bei Kammern (Niederösterreich), Beiträge zur Paläontologie, 21, 21-31, 1996.

Frank, C. and Rabeder, G.: Grubgraben bei Kammern, in: Pliozäne und pleistozäne Faunen Österreichs, edited by: Döppes, D. und Rabeder, G., Mitteilungen der Kommission für Quartärforschung, Österreichische Akademie der Wissenschaften, 10, 16-20, 1997.

Frechen, M., Oches, E. A., and Kohfeld, K. E.: Loess in Europe mass accumulation rates during the Last Glacial Period, Quaternary Sci. Rev., 22, 1835-1857, 2003.

Fúköh, L.: Holocene malacology in Hungary, Scripta Geologica, Special Issue 2, 121-125, 1993.

Gavrilov, M. B., Marković, S. B., Schaetzl, R. J., Tošić, I., Zeeden, C., Obreht, I., Sipos, G., Ruman, A., Putniković, S., Emunds, K., Perić, Z., Hambach, U., and Lehmkuhl, F.: Prevailing surface winds in Northern Serbia in the recent and past time periods; modern- and past dust deposition, Aeolian Res., 31, 117-129, https://doi.org/10.1016/j.aeolia.2017.07.008, 2018.

Gocke, M.: Pedogenic carbonates in loess formation rates, formation conditions and source apportionment assessed by isotopes and molecular proxies, Dissertation, Bayreuth, 1-179, https:// epub.uni-bayreuth.de/id/eprint/360 (last access: 18 June 2021), 2011.

Gocke, M., Pustovoytov, K., Kühn, P., Wiesenberg, G. L. B., Löscher, M., and Kuzyakov, Y.: Carbonate rhizoliths in loess and their implications for paleoenvironmental reconstruction revealed by isotopic composition: $\delta^{13} \mathrm{C},{ }^{14} \mathrm{C}$, Chem. Geol., 283, 251-260, 2011.

Gocke, M., Hambach, U., Eckmeier, E., Schwark, L., Zöller, L., Fuchs, M., Löscher, M., and Wiesenberg, G. L. B.: Introducing an improved multi-proxy approach for paleoenvironmental reconstruction of loess-paleosol archives applied on the Late Pleis- 
tocene Nussloch sequence (SW Germany), Paleogeogr. Paleocl., 410, 300-315, 2014.

Goff, K., Schaetzl, R. J., Chakraborty, S., Weindorf, D. C., Kasmerchak, C., and Bettis III, E. A.: Impact of sample preparation methods for characterizing the geochemistry of soils and sediments by portable X-ray fluorescence, Soil Sci. Soc. Am. J., 84, 131-143, https://doi.org/10.1002/saj2.20004, 2020.

Haesaerts, P.: Stratigraphy of the Grubgraben Loess Sequence, in: The epigravettian site of Grubgraben, Lower Austria: The 1986 and 1987 excavations, edited by: Montet-White, A., Eraul, 40, 15-35, OCLC-number 24578227, 1990.

Haesaerts, P. and Damblon, F.: The Late Palaeolithic Site of Kammern-Grubgraben (Lower Austria). Additional Data on Loess Stratigraphy and Palaeoenvironment, Archaeologia Austriaca, 100, 255-269, 2016.

Haesaerts, P., Damblon, F., Neugebauer-Maresch, C., and Einwögerer, T.: Radiocarbon Chronology of the Late Palaeolithic Loess Site of Kammern-Grubgraben (Lower Austria), Archaeologia Austriaca, 100, 271-277, 2016.

Händel, M., Simon, U., Einwögerer, T., and Neugebauer-Maresch, C.: Loess deposits and the conservation of the archaeological record - The Krems-Wachtberg example, Quatern. Int., 198, 4650, 2009.

Händel, M., Einwögerer, T., Simon, U., and Neugebauer-Maresch, C.: Krems-Wachtberg excavations 2005-12: Main profiles, sampling, stratigraphy, and site formation, Quatern. Int., 351, 38-49, 2014.

Händel, M., Simon, U., Maier, A., Brandl, M., Groza-Săcaciu, S. M., Timar-Gabor, A., and Einwögerer, T.: Kammern-Grubgraben revisited - First results from renewed investigations at a wellknown LGM site in east Austria, Quatern. Int., 587-588, 137157, https://doi.org/10.1016/j.quaint.2020.06.012, 2021.

Hatté, C., Fotugne, M., Rousseau, D.-D., Antoine, P., Zöller, L., Tisnérat-Laborde, N., and Bentaleb, I: $\delta^{13} \mathrm{C}$ variations of loess organic matter as a record of the vegetation response to climatic changes during Weichselian, Geology, 26, 583-586, 1998.

Heiri, O., Lotter, A. F., and Lemcke, G.: Loss on ignition as a method for estimating organic and carbonate content in sediments: reproducibility and comparability of results, J. Paleolimnol., 25, 101-110, 2001.

Hughes, P. D. and Gibbard, P. L.: A stratigraphical basis for the Last Glacial Maximum (LGM), Quatern. Int., 383, 174-185, https://doi.org/10.1016/j.quaint.2014.06.006, 2015.

Koeniger, P., Barta, G., Thiel, C., Bajnóczi, B., Novothny, Á., Horváth, E., Techmer, A., and Frechen, M.: Stable isotope composition of bulk and secondary carbonates from the Quaternary loess-paleosol sequence in Süttő, Hungary, Quatern. Int., 319, 38-49, 2014.

Kovács, J., Moravcová, M., Újvári, G., and Pintér, A. G.: Reconstructing the paleoenvironment of East Central Europe in the Late Pleistocene using oxygen and carbon isotopic signal of tooth in large mammal remains, Quatern. Int., 276-277, 145$154,2012$.

Krolopp, E. and Sümegi, P.: Palaeoecological reconstruction of the late Pleistocene, based on loess malacofauna in Hungary, GeoJournal, 36, 213-222, 1995.

Lambeck, K., Rouby, H., Purcell, A., Sun, Y., and Sambridge, M.: Sea level and global ice volumes from the Last Glacial Maximum to the Holocene, P. Natl. Acad. Sci. USA, 111, 15296-15303, https://doi.org/10.1073/pnas.1411762111, 2014.

Lehmkuhl, F., Zens, J., Krauß, L., Schulte, P., and Kels, H.: Loesspaleosol sequences at the northern European loess belt in Germany: Distribution, geomorphology and stratigraphy, Quaternary Sci. Rev., 153, 11-30, 2016.

Lehmkuhl, F., Nett, J. J., Pötter, S., Schulte, P., Sprafke, T., Jary, Z., Antoine, P., Wacha, L., Wolf, D., Zerboni, A., Hošek, J., Marković, S. B., Obreht, I., Sümegi, P., Veres, D., Zeeden, C., Boemke, B.. Schaubert, V., Viehweger, J., and Hambach, U.: Loess landscapes of Europe - Mapping, geomorphology, and zonal differentiation, Earth-Sci. Rev., 215, 103496, https://doi.org/10.1016/j.earscirev.2020.103496, 2021.

Liang, L., Sun, Y., Yao, Z., Liu, Y., and Wu, F.: Evaluation of highresolution elemental analyses of Chinese loess deposits measured by X-ray fluorescence core scanner, CATENA, 92, 75-82, 2012.

Logan, B.: The hunted of Grubgraben: an analysis of faunal remains, in: The Epigravettian Site of Grubgraben, Lower Austria: The 1986 and 1987 Excavations, edited by: Montet-White, A. ERAUL - Études et Recherche Archéologiques de l'Université de Liège 40, Liège 1990, 65-91, OCLC-number 24578227, 1990.

Lowe, J. and Walker, M.: Reconstructing Quaternary Environments, 3rd edition, Routledge, London, New York, https://doi.org/10.4324/9781315797496, 2015.

Ložek, V.: Die Quartärmollusken der Tschechoslowakei, Rozpravy ústředního ústavo geologického, 31, 374 pp., ark:/13960/t2996v274, 1964.

Ložek, V.: Faunengeschichtliche Grundlinien zur spät- und nacheiszeitlichen Entwicklung der Molluskenbestände in Mitteleuropa. Rozpravy Českoslov, Akad. Věd, Řada Mat. Přirod. Věd., 92, 106 pp., 1982.

Ludwig, P., Gavrilov, M. B., Marković, S. B., Újvári, G., and Lehmkuhl, F.: Simulated regional dust cycle in the Carpathian Basin and the Adriatic Sea region during the Last Glacial Maximum, Quatern. Int., 581-582, 114-127, 2021.

Luetscher, M., Boch, R., Sodemann, H., Spötl, C., Cheng, H., Edwards, R. L., Frisia, S., Hof, F., and Müller, W.: North Altlantic storm track changes during the Last Glacial Maximum recorded by Alpine speleothems, Nat. Commun., 6, 1-6, https://doi.org/10.1038/ncomms7344, 2015.

Luo, X., Wang, H., An, Z., Zhang, Z., and Liu, W.: Carbon and oxygen isotopes of calcified root cells, carbonate nodules and total inorganic carbon in the Chinese loess-paleosol sequence: The application of paleoenvironmental studies, J. Asian Earth Sci., 201, 104515, https://doi.org/10.1016/j.jseaes.2020.104515, 2020.

Maier, A., Stojakowits, P., Mayr, C., Pfeifer, S., Preusser, F., Zolitschka, B., Anghelinu, M., Bobak, D., Duprat-Oualid, F., Einwögerer, T., Hambach, U., Händel, M., Kaminská, L., Kämpf, L., Łanczont, M., Lehmkuhl, F., Ludwig, P., Magyari, E., Mroczek, P., Nemergut, A., Nerudová, Z., Niţă, L., Polanská, M., Połtowicz-Bobak, M., Rius, D., Römer, W., Simon, U., Škrdla, P., Újvári, G., and Veres, D.: Cultural evolution and environmental change in Central Europe between 40 and $15 \mathrm{ka}$, Quatern. Int., 581-582, 225-240, 2021. 
Mania, D.: Paläoökologie, Faunenentwicklung und Stratigraphie des Eiszeitalters im mittleren Elbe-Saalegebiet auf Grund von Molluskengesellschaften, Geologie, 21, 1-175, 1973.

Marković, S. B., Stevens, T., Kukla, G. J., Hambach, U., Fitzsimmons, K. E., Gibbard, P., Buggle B., Zech, M., Guo, Z., Hao, Q., Wu, H., O’Hara Dhand, K., Smalley, I. J., Újvári, G., Sümegi, P., Timar-Gabor, A., Veres, F. Sirocko, D., Vasiljević, D. A., Jary, Z., Svensson, A., Jović, V., Lehmkuhl, F., Kovács, J., and Svirčev, Z.: Danube loess stratigraphy - Towards a pan-European loess stratigraphic model, Earth-Sci. Rev., 148, 228-258, 2015.

Martin-Puertas, C., Tjallingii, R., Bloemsma, M., and Brauer, A.: Varved sediment responses to early Holocene climate and environmental changes in Lake Meerfelder Maar (Germany) obtained from multivariate analyses of micro X-ray fluorescence core scanning data, J. Quaternary Sci., 32, 427-436, 2017.

Mayr, C., Brandlmeier, B., Diersche, V., Stojakowits, P., Kirscher, U., Matzke-Karasz, R., Bachtadse V., Eigler M., Haas U., Lempe B., Reimer P., and Spötl, C.: Nesseltalgraben, a new reference section of the last glacial period in southern Germany, J. Paleolimnol., 58, 213-229, 2017a.

Mayr, C., Matzke-Karasz, R., Stojakowits, P., Lowick, S. E., Zolitschka, B., Heigl, T., Mollath, R., Theuerkauf, M., Weckend, M.-O., Bäumler, R., and Gregor, H.-J.: Palaeoenvironments during MIS 3 and MIS 2 inferred from lacustrine intercalations in the loess-palaeosol sequence at Bobingen (southern Germany), E\&G Quaternary Sci. J., 66, 73-89, https://doi.org/10.5194/egqsj-66-73-2017, 2017b.

Mayr, C., Stojakowits, P., Lempe, B., Blaauw, M., Diersche, V., Grohganz, M., López Correa, M., Ohlendorf, C., Reimer, P., and Zolitschka, B.: High-resolution geochemical record of environmental changes during MIS 3 from the northern Alps (Nesseltalgraben, Germany), Quaternary Sci. Rev., 218, 122-136, https://doi.org/10.1016/j.quascirev.2019.06.013, 2019.

Meyer-Heintze, S., Sprafke, T., Schulte, P., Terhorst, B., Lomax, J., Fuchs, M., Lehmkuhl, F., Neugebauer-Maresch, C., Einwögerer, T., Händel, M., Simon, U., and Castillo, B. S.: The MIS 3/2 transition in a new loess profile at Krems-Wachtberg East - A multimethodological approach, Quatern. Int., 464, 370-385, 2018.

Mix, A. C., Bard, E., and Schneider, R.: Environmental processes of the ice age: land, oceans, glaciers (EPILOG), Quaternary Sci. Rev., 20, 627-657, https://doi.org/10.1016/S02773791(00)00145-1, 2001

Moine, O., Antoine, P., Hatté, C., Landais, A., Mathieu, J., Prud'homme, C., and Rousseau, D.-D.: The impact of Last Glacial climate variability in wet-European loess revealed by radiocarbon dating of fossil earthworm granules, P. Natl. Acad. Sci. USA, 114, 6209-6214, https://doi.org/10.1073/pnas.1614751114, 2017.

Monger, C. H.: Pedogenic carbonate: links between biotic and abiotic $\mathrm{CaCO}_{3}$, in: Proc. 17th World Congress of Soil Science, 14 21 August 2002, Bangkok, Thailand, 897, 1-9, OCLC-number: 796897124, 2002.

Montet-White, A. (Ed.): The Epigravettian Site of Grubgraben, Lower Austria: The 1986 and 1987 Excavations, ERAUL Études et Recherche Archéologiques de l'Université de Liège 40, Liège 1990, 159-162, OCLC-number 24578227, 1990.

Montet-White, A., Haesaerts, P., and Logan, B.: The Epigravettian of Grubgraben: an overview of the 1986/87 excavations, in: The Epigravettian Site of Grubgraben, Lower Austria: The 1986 and 1987 Excavations, edited by: Montet-White, A., ERAUL Études et Recherche Archéologiques de l'Université de Liège 40, Liège 1990, 159-162, OCLC-number 24578227, 1990.

Muhs, D. R. and Bettis III, E. A.: Geochemical variations in Peoria loess of Western Iowa indicate paleowinds of midcontinental North America during last glaciation, Quaternary Res., 53, 4961, 2000.

Neugebauer-Maresch, C., Einwögerer, T., Richter, J., Maier, A., and Hussain, S. T.: Kammern-Grubgraben. Neue Erkenntnisse zu den Grabungen 1989-1994, Archaeologia Austriaca, 100, 225-254, https://doi.org/10.1553/archaeologia100s225, 2016.

Nigst, P. R., Viola, T. B., Haesaerts, P., Blockley, S., Damblon, F., Frank, C., Fuchs, M., Götzinger, M., Hambach, U., Mallol, C., Moreau, L., Niven, L., Richards, M., Richter, D., Zöller, L., Trnka, G., and Hublin, J.-J.: New research on the Aurignacian of Central Europe: A first note on the 2006 fieldwork at Willendorf II, Quartär, 55, 9-15, 2008.

Novothny, Á., Frechen, M., Horváth, E., Wacha, L., and Rolf, C.: Investigating the penultimate and last glacial cycles of the Süttô loess section (Hungary) using luminescence dating, highresolution grain size, and magnetic susceptibility data, Quatern. Int., 234, 75-85, 2011.

Oehlerich, M., Baumer, M., Lücke, A., and Mayr, C.: Effects of organic matter on carbonate stable isotope ratios $\left(\delta^{13} \mathrm{C}, \delta^{18} \mathrm{O}\right.$ values) - implications for analyses of bulk sediments, Rapid Commun. Mass Sp., 27, 707-712, 2013.

O'Leary, M. H.: Carbon isotope fractionation in plants, Phytochemistry, 20, 553-567, 1981.

Pécsi, M.: Loess is not just the accumulation of dust, Quatern. Int., 7-8, 1-21, 1990.

Pigati, J. S., Rech, J. A., and Nekola, J. C.: Radiocarbon dating of small terrestrial gastropod shells in North America, Quat. Geochronol., 5, 519-532, 2010.

Porter, S.: Chinese loess record of monsoon climate during the last glacial-interglacial cycle, Earth-Sci. Rev., 54, 115-128, 2001.

Pötter, S., Schmitz, A., Lücke, A., Schulte, P., Obreht, I., Zech, M., Wissel, H., Marković, S. B., and Lehmkuhl, F.: Middle to Late Pleistocene environments based on stable organic carbon and nitrogen isotopes of loess-palaeosol sequences from the Carpathian Basin, Boreas, 50, 184-204, https://doi.org/10.1111/bor.12470, 2020.

Profe, J. and Ohlendorf, C.: X-ray fluorescence scanning of discrete samples - An economical perspective, Quatern. Int., 514, 68-75, 2019.

Profe, J., Wacha, L., Frechen, M., Ohlendorf, C., and Zolitschka, B.: XRF scanning of discrete samples - A chemostratigraphic approach exemplified for loess-paleosol sequences from the Island of Susak, Croatia, Quatern. Int., 494, 34-51, 2018a.

Profe, J., Neumann, L., Novothny, Á., Barta, G., Rolf, C., Frechen, M., Ohlendorf, C., and Zolitschka, B.: Paleoenvironmental conditions and sedimentation dynamics in Central Europe inferred from geochemical data of the loess-paleosol sequence at Süttő (Hungary), Quaternary Sci. Rev., 196, 1-17, https://doi.org/10.1016/j.quascirev.2018.07.034, 2018 b.

Pustovoytov, K. and Terhorst, B.: An isotope study of a late Quaternary loess-paleosol sequence in SW Germany, Rev. Mex. Cienc. Geol., 21, 88-93, 2004.

Rasmussen, S. O., Bigler, M., Blockley, S. P., Blunier, T., Buchardt, S. L., Clausen, H. B., Cvijanovic, I., Dahl-Jensen, D., Johnsen, 
S. J., Fischer, H., Gkinis, V., Guillevic, M., Hoek, W. Z., Lowe, J. J., Pedro, J B., Popp, T., Seierstadt, I. K., Steffensen, J. P., Svensson, A. M., Vallelonga, P., Vinther, B. M., Walker, M. J. C., Wheatley, J. J., and Winstrup, M.: A stratigraphic framework for abrupt climatic changes during the Last Glacial period based on three synchronized Greenland ice-core records: refining and extending the INTIMATE event stratigraphy, Quaternary Sci. Rev., 106, 14-28, 2014.

Reimer, P. J., Austin, W. E. N., Bard, E., Bayliss, A., Blackwell, P. G., Bronk Ramsey, C., Butzin, M., Cheng, H., Edwards, R. L., Friedrich, M., Grootes, P. M., Guilderson, T. P., Hajdas, I., Heaton, T. J., Hogg, A. G., Hughen, K. A., Kromer, B., Manning, S. W., Muscheler, R., Palmer, J. G., Pearson, C., van der Plicht, J., Reimer, R. W., Richards, D. A., Scott, E. M., Southon, J. R., Turney, C. S. M., Wacker, L., Adolphi, F., Büntgen, U., Capano, M., Fahrni, S. M., Fogtmann-Schulz, A., Friedrich, R., Köhler, P., Kudsk, S., Miyake, F., Olsen, J., Reinig, F., Sakamoto, M., Sookdeo, A., and Talamo, S.: The IntCal20 Northern Hemisphere Radiocarbon Age Calibration Curve (0-55 cal kBP), Radiocarbon, 62, 725-757, 2020.

Renssen, H., Kasse, C., Vandenberghe, J., and Lorenz, S. J.: Weichselian Late Pleniglacial surface winds over northwest and central Europe: a model-data comparison, J. Quaternary Sci., 22, 281293, 2007.

Rounick, J. S. and Winterbourn, M. J.: Stable carbon isotopes and carbon flow in ecosystems, BioScience, 36, 171-177, 1986.

Rousseau, D. D., Antoine, P., Hatté, C., Lang, A., Zöller, L., Fontugne, M., Othman, D. B., Luck, J. M., Moine, O., Labonne, M., Bentaleb, I., and Jolly, D.: Abrupt millennial climatic changes from Nussloch (Germany) Upper Weichselian eolian records during the Last Glaciation, Quaternary Sci. Rev., 21, 1577-1582, 2002.

Runge, E. C. A., Goh, K. M., and Rafter, T. A.: Radiocarbon Chronology and Problems in Its Interpretation for Quaternary Loess Deposits-South Canterbury, New Zealand, Soil Sci. Soc. Am. Pro., 37, 742-746, 1973.

Schatz, A. K., Zech, M., Buggle, B., Gulyás, S., Hambach, U., Marković, S. B., Sümegi, P., and Scholten, T.: The late Quaternary loess record of Tokaj, Hungary: Reconstructing palaeoenvironment, vegetation and climate using stable $\mathrm{C}$ and $\mathrm{N}$ isotopes and biomarkers, Quatern. Int., 240, 52-61, 2011.

Smalley, I., O’Hara-Dhand, K., Wint, J., Machalett, B., Jary, Z., and Jefferson, I.: Rivers and loess: The significance of long river transportation in the complex event-sequence approach to loess deposit formation, Quatern. Int., 198, 7-18, 2009.

Smalley, I., Marković, S. B., and Svirčev, Z.: Loess is [almost totally formed by] the accumulation of dust, Quatern. Int., 240, 4-11, 2011.

Sprafke, T.: Löss in Niederösterreich: Archiv quartärer Klima- und Landschaftsveränderungen, Dissertation, Würzburg University Press, Würzburg, 1-272, https://doi.org/10.25972/WUP-978-395826-039-9, 2016.

Sprafke, T., Schulte, P., Meyer-Heintze, S., Händel, M., Einwögerer, T., Simon, U., Peticzka, R., Schäfer, C., Lehmkuhl, F., and Terhorst, B.: Paleoenvironments from robust loess stratigraphy using high-resolution color and grain-size data of the last glacial Krems-Wachtberg record (NE Austria), Quaternary Sci. Rev., 248, 106602, https://doi.org/10.1016/j.quascirev.2020.106602, 2020.
Stojakowits, P., Mayr, C., Ivy-Ochs, S., Preusser, F., Reitner, J. M., and Spötl, C.: Environments at the MIS 3/2 transition in the northern Alps and their foreland, Quatern. Int., 581-582, 99-113, 2021.

Stuiver, M., Reimer, P. J., and Reimer, R. W: CALIB 8.2., http: //calib.org/calib/, last access: 21 October 2020.

Sun, Y., Liang, L., Bloemendal, J., Li, Y., Wu, F., Yao, Z., and Liu, Y.: High-resolution scanning XRF investigation of Chinese loess and its implications for millennial-scale monsoon variability, J. Quaternary Sci., 31, 191-202, 2016.

Svoboda, J.: The Pavlov Site, Czech Republic: Lithic Evidence from the Upper Palaelithic, J. Field Archaeol., 21, 69-81, https://doi.org/10.1179/jfa.1994.21.1.69, 1994.

Svoboda, J., Hladilová, Š., Horáček, I., Kaiser, J., Králík, M., Novák, J., Novák, M., Pokorný, P., Sázelová, S., Smolíková, L., and Zikmund, T.: Dolní Věstonice IIa: Gravettian microstratigraphy, environment, and the origin of baked clay production in Moravia, Quatern. Int., 359-360, 195-210, 2015.

Terhorst, B., Tiehl, C., Peticzka, R., Sprafke, T., Frechen, M., Fladerer, F. A., Roetzel, R., and Neugebauer-Maresch, C.: Casting new light on the chronology of the loess/paleosol sequences in Lower Austria, Quaternary Sci. J., 60, 270-277, https://doi.org/10.3285/eg.60.2-3.04, 2011.

Terhorst, B., Kühn, P., Damm, B., Hambach, U., Meyer-Heintze, S., and Sedov, S.: Palaeoenvironmental fluctuations as recorded in the loess-paleosol sequence of the Upper Paleolithic site KremsWachtberg, Quatern. Int., 351, 67-82, 2014.

Teyssandier, N. and Zilhão, J.: On the Entity and Antiquity of the Aurignacian at Willendorf (Austria): Implications for Modern Human Emergence in Europe, Journal of Paleolithic Archaeology, 1, 107-138, 2018.

Thiel, C., Buylaert, J.-P., Murray, A., Terhorst, B., Hofer, I., Tsukamoto, S., and Frechen, M.: Luminescence dating of the Stratzing loess profile (Austria) - Testing the potential of an elevated temperature post-IR IRSL protocol, Quatern. Int., 234, 23 31, 2011a.

Thiel, C., Terhorst, B., Jaburová, I., Buylaert, J.-P., Murray, A. S., Fladerer, F. A., Damm, B., Frechen, M., and Ottner, F.: Sedimentation and erosion processes in Middle to Late Pleistocene sequencesexposed in the brickyard of Langenlois/Lower Austria, Geomorphology, 135, 295-307, https://doi.org/10.1016/j.geomorph.2011.02.011, 2011b.

Tomášová, S.: A site in history: archaeology at Dolní Věstonice/Unterwisternitz, Antiquity, 69, 301-316, 1995.

Újvári, G. and Klötzli, U.: U-Pb ages and Hf isotopic composition of zircons in Austrian last glacial loess: constraints on heavy mineral sources and sediment transport pathways, Int. J. Earth Sci., 104, 1365-1385, https://doi.org/10.1007/s00531-014-1139$\mathrm{x}, 2015$.

Újvári, G., Molnár, M., Novothny, Á., Páll-Gergely, B., Kovács, J., and Várhegyi, A.: AMS ${ }^{14} \mathrm{C}$ and OSL/IRSL dating of the Dunaszekcső loess sequence (Hungary): chronology for 20 to $150 \mathrm{ka}$ and implications for establishing reliable age-depth models for the last $40 \mathrm{ka}$, Quaternary Sci. Rev., 106, 140-154, 2014.

Újvári, G., Molnár, M., and Páll-Gergely, B.: Charcoal and mollusc shell ${ }^{14} \mathrm{C}$-dating of the Dunaszekcsố loess record, Hungary, Quat. Geochronol., 35, 43-53, 2016a.

Újvári, G., Kok, J. F., Varga, G., and Kovács, J.: The physics of wind-blown loess: implications for grain size proxy inter- 
pretations in Quaternary paleoclimate studies, Earth-Sci. Rev., 154, 247-278, https://doi.org/10.1016/j.earscirev.2016.01.006, $2016 \mathrm{~b}$.

Urbanek, M.: A review of archaeological research at Grubgraben prior to 1980, in: The Epigravettian Site of Grubgraben, Lower Austria: The 1986 and 1987 Excavations, edited by: MontetWhite, A., ERAUL - Études et Recherche Archéologiques de l'Université de Liège 40, Liège 1990, 7-13, OCLC-number 24578227, 1990.

Vanderberghe, J.: Grain size of fine-grained windblown sediment : A powerful proxy for process identification, Earth-Sci. Rev., 121, 18-30, https://doi.org/10.1016/j.earscirev.2013.03.001, 2013.

Vanderberghe, J., Zhisheng, A., Nugteren, G., Huayu, L., and Van Huissteden, K.: New absolute time scale for the Quaternary climate in Chinese loess region by grain size analysis, Geology, 25, 35-38, 1997.

Veres, D., Tecsa, V., Gerasimenko, N., Zeeden, C., Hambach, U., and Timar-Gabor, A.: Short-term soil formation events in last glacial east European loess, evidence from multi-method luminescence dating, Quaternary Sci. Rev., 200, 34-51, 2018.

Wang, H. and Greenberg, S. E.: Reconstructing the response of $\mathrm{C}_{3}$ and $\mathrm{C}_{4}$ plants to decadal-scale climate change during the late Pleistocene in southern Illinois using isotope analyses of calcified rootlets, Quaternary Res., 67, 136-142, 2007.

Wang, Z., Zhao, H., Dong, G., Zhou, A., Liu, J., and Zhang, D.: Reliability of radiocarbon dating on various fractions of loess-soil sequence for Dadiwan section in the western Chinese Loess Plateau, Front. Earth Sci., 8, 540-546, https://doi.org/10.1007/s11707-014-0431-1, 2014.

Ward, C. R., Kelloway, S. J., Vohra, J., French, D., Cohen, D. R., Marjo, C. E., and Wainwright, I. E.: In-situ inorganic analysis of coal seams using a hand-held field-portable XRF Analyser, Int. J. Coal Geol., 191, 172-188, 2018.
Weltje, G., Bloemsma, M., Tjallingii, R., Heslop, D., Röhl, U., Croudace, I.: Prediction of Geochemical Composition from XRF Core Scanner Data: A New Multivariate Approach Including Automatic Selection of Calibration Samples and Quantification of Uncertainties, in: Micro-XRF Studies of Sediment Cores, edited by: Croudace, I. and Rothwell, R., Springer, Dordrecht, 507-534, https://doi.org/10.1007/978-94-017-9849-5_21, 2015.

West, D.: Hunting strategies in Central Europe during the last glacial maximum, British Archaeological Reports International Series 672, Hadrian Books, Oxford, 1-153, ISBN 9780860549123, 1997.

Xu, B., Gu, Z., Han, J., Hao, Q., Lu, Y., Wang, L., Wu, N., and Peng, Y.: Radiocarbon age anomalies of land snail shells in the Chinese Loess Plateau, Quat. Geochronol., 6, 383-389, 2011.

Zech, M., Zech, R., and Glaser, B.: A 240,000-year stable carbon and nitrogen isotope record from a loess-like palaeosol sequence in the Tumara Valley, Northeast Siberia, Chem. Geol., 242, 307318, 2007.

Zech, R., Zech, M., Marković, S., Hambach, U., and Huang, Y.: Humid glacials, arid interglacials? Critical thoughts on pedogenesis and paleoclimate based on multi-proxy analyses of the loess-paleosol sequence Crvenka, Northern Serbia, Palaeogeogr. Palaeocl., 387, 165-175, 2013.

Zeeden, C. and Hambach, U.: Magnetic Susceptibility Properties of Loess from the Willendorf Archaeological Site: Implications for the Syn/Post-Depositional Interpretation of Magnetic Fabric, Front. Earth Sci., 8, 1-11, https://doi.org/10.3389/feart.2020.599491, 2021. 